\title{
The magnitude of the snow-sourced reactive nitrogen flux to the boundary layer in the Uintah Basin, Utah, USA
}

\author{
Maria Zatko $^{1}$, Joseph Erbland ${ }^{2,3}$, Joel Savarino ${ }^{2,3}$, Lei Geng ${ }^{1, a}$, Lauren Easley ${ }^{4, b}$, Andrew Schauer ${ }^{5}$, Timothy Bates ${ }^{7}$, \\ Patricia K. Quinn $^{6}$, Bonnie Light ${ }^{8}$, David Morison ${ }^{8, c}$, Hans D. Osthoff ${ }^{9}$, Seth Lyman ${ }^{10}$, William Neff ${ }^{11}$, Bin Yuan $^{11,12}$, \\ and Becky Alexander ${ }^{1}$ \\ ${ }^{1}$ Department of Atmospheric Sciences, University of Washington, Seattle 98195, USA \\ ${ }^{2}$ Université Grenoble Alpes, LGGE, 38000 Grenoble, France \\ ${ }^{3}$ CNRS, LGGE, 38000 Grenoble, France \\ ${ }^{4}$ Department of Chemistry, University of Washington, Seattle, Washington 98195, USA \\ ${ }^{5}$ Earth and Space Sciences, University of Washington, Seattle, Washington 98195, USA \\ ${ }^{6}$ Pacific Marine Environmental Laboratory, National Oceanic and Atmospheric Administration, Seattle, \\ Washington 98115, USA \\ ${ }^{7}$ Joint Institute for the Study of the Atmosphere and Oceans, University of Washington, Seattle, Washington 98195, USA \\ ${ }^{8}$ Polar Science Center, Applied Physics Laboratory, University of Washington, Seattle, Washington 98195, USA \\ ${ }^{9}$ Department of Chemistry, University of Calgary, 2500 University Drive NW, Calgary, AB T2N 1N4, Canada \\ ${ }^{10}$ Bingham Entrepreneurship and Energy Research Center, Utah State University, 320 Aggie Boulevard, Vernal, \\ Utah 84078, USA \\ ${ }^{11}$ Cooperative Institute for Research in the Environmental Sciences, University of Colorado, Boulder, Colorado 80309, USA \\ ${ }^{12}$ Chemical Sciences Division, Earth System Research Laboratory, National Oceanic and Atmospheric Administration, \\ Boulder, Colorado 80305, USA \\ ${ }^{a}$ now at: Université Grenoble Alpes, LGGE, 38000 Grenoble, France, CNRS, LGGE, 38000 Grenoble, France \\ b current address: DSG Solutions, LLC, Shoreline, WA, 98133, USA \\ ${ }^{c}$ now at: Department of Physics and Astronomy, University of Utah, Salt Lake City, Utah 84112, USA
}

Correspondence to: Becky Alexander (beckya@uw.edu)

Received: 13 April 2016 - Published in Atmos. Chem. Phys. Discuss.: 17 May 2016

Revised: 12 August 2016 - Accepted: 1 October 2016 - Published: 9 November 2016

\begin{abstract}
Reactive nitrogen $\left(\mathrm{N}_{\mathrm{r}}=\mathrm{NO}, \mathrm{NO}_{2}, \mathrm{HONO}\right)$ and volatile organic carbon emissions from oil and gas extraction activities play a major role in wintertime ground-level ozone exceedance events of up to $140 \mathrm{ppb}$ in the Uintah Basin in eastern Utah. Such events occur only when the ground is snow covered, due to the impacts of snow on the stability and depth of the boundary layer and ultraviolet actinic flux at the surface. Recycling of reactive nitrogen from the photolysis of snow nitrate has been observed in polar and midlatitude snow, but snow-sourced reactive nitrogen fluxes in mid-latitude regions have not yet been quantified in the field. Here we present vertical profiles of snow nitrate concentration and nitrogen isotopes $\left(\delta^{15} \mathrm{~N}\right)$ collected during the Uintah Basin Winter Ozone Study 2014 (UBWOS 2014), along
\end{abstract}

with observations of insoluble light-absorbing impurities, radiation equivalent mean ice grain radii, and snow density that determine snow optical properties. We use the snow optical properties and nitrate concentrations to calculate ultraviolet actinic flux in snow and the production of $\mathrm{N}_{\mathrm{r}}$ from the photolysis of snow nitrate. The observed $\delta^{15} \mathrm{~N}\left(\mathrm{NO}_{3}^{-}\right)$is used to constrain modeled fractional loss of snow nitrate in a snow chemistry column model, and thus the source of $\mathrm{N}_{\mathrm{r}}$ to the overlying boundary layer. Snow-surface $\delta^{15} \mathrm{~N}_{\left(\mathrm{NO}_{3}^{-}\right)}$measurements range from -5 to $10 \% o$ and suggest that the local nitrate burden in the Uintah Basin is dominated by primary emissions from anthropogenic sources, except during fresh snowfall events, where remote $\mathrm{NO}_{x}$ sources from beyond the basin are dominant. Modeled daily averaged snow-sourced 
$\mathrm{N}_{\mathrm{r}}$ fluxes range from 5.6 to $71 \times 10^{7}$ molec $\mathrm{cm}^{-2} \mathrm{~s}^{-1}$ over the course of the field campaign, with a maximum noontime value of $3.1 \times 10^{9}$ molec $\mathrm{cm}^{-2} \mathrm{~s}^{-1}$. The top-down emission estimate of primary, anthropogenic $\mathrm{NO}_{x}$ in Uintah and Duchesne counties is at least 300 times higher than the estimated snow $\mathrm{NO}_{x}$ emissions presented in this study. Our results suggest that snow-sourced reactive nitrogen fluxes are minor contributors to the $\mathrm{N}_{\mathrm{r}}$ boundary layer budget in the highly polluted Uintah Basin boundary layer during winter 2014.

\section{Introduction}

Ozone $\left(\mathrm{O}_{3}\right)$ has adverse respiratory effects, is an effective greenhouse gas (UNEP, 2011), and, through formation of the hydroxyl radical, influences the oxidizing capacity of the atmosphere (Thompson, 1992). Ozone precursors include volatile organic compounds (VOCs) emitted from vegetation, biomass burning, and fossil fuel combustion (Guenther et al., 1995; Warneke et al., 2014) and nitrogen oxides $\left(\mathrm{NO}_{x}=\mathrm{NO}+\mathrm{NO}_{2}\right)$ emitted from fossil fuel combustion, biomass burning, soil microbial activity, lightning, and photochemical reactions in snow (Delmas et al., 1997; Grannas et al., 2007; Logan, 1983). Maximum boundary layer $\mathrm{O}_{3}$ concentrations are typically observed during the summer in major cities, where $\mathrm{O}_{3}$ precursors are abundant, and when conditions favor efficient $\mathrm{O}_{3}$ production (high ultraviolet, $\mathrm{UV}$, radiation) and air stagnation. High $\mathrm{O}_{3}$ concentrations in the boundary layer exceeding $100 \mathrm{ppbv}$ were measured in winter 2005 in the Upper Green River basin in rural Wyoming (Schnell et al., 2009), which is well above the current Environmental Protection Agency (EPA) National Ambient Air Quality Standard (NAAQS) $8 \mathrm{~h}$ average limit of 70 ppbv. High wintertime $\mathrm{O}_{3}$ episodes have also been observed in the Uintah Basin in rural Utah (Martin et al., 2011), and in both basins, these $\mathrm{O}_{3}$ episodes only occur when the ground is snow covered (Oltmans et al., 2014). The Upper Green River basin and the Uintah Basin are regions of major oil and gas development, and the production of oil and natural gas in the Upper Green River basin and the Uintah Basin is expected to increase through at least 2020 (US EIA, 2014).

These wintertime high $\mathrm{O}_{3}$ episodes motivated a series of field campaigns, including the Upper Green Winter Ozone Study (UGWOS 2011, UGWOS 2012) and the Uintah Basin Winter Ozone Study (UBWOS 2012, UBWOS 2013, UBWOS 2014). Results from these field campaigns (Gilman et al., 2013; Helmig et al., 2014; Oltmans et al., 2014; Warneke et al., 2014; Schnell et al., 2009) and subsequent modeling studies (Ahmadov et al., 2015; Carter and Seinfeld, 2012; Edwards et al., 2013, 2014; Field et al., 2015; Rappenglück et al., 2014) reveal that emissions of $\mathrm{NO}_{x}$ and VOCs from oil and gas extraction, combined with stagnant meteorological conditions, enhanced boundary layer UV radiation due to the high UV albedo of snow (Warren et al., 2006), and reduced
$\mathrm{O}_{3}$ loss through surface deposition due to snow cover (Ahmadov et al., 2015), trigger high boundary layer $\mathrm{O}_{3}$ episodes in these basins. Ozone exceedance events occur only when the ground is snow covered because snow aids in the formation and maintenance of a stable air mass and reflects UV radiation upwards into the boundary layer. Ozone exceedance events end when stable boundary layers are disrupted by the passage of storm fronts, which often deposit snow. Modeling studies were used to determine whether $\mathrm{O}_{3}$ formation in these regions is $\mathrm{NO}_{x}$-sensitive or VOC-sensitive, which is necessary information for the enactment of effective regulations aimed to reduce boundary layer $\mathrm{O}_{3}$ abundance. Modeling results from Edwards et al. (2014) suggest that the Uintah Basin is in an $\mathrm{O}_{3}$ formation regime on the boundary between VOC-sensitive and $\mathrm{NO}_{x}$-sensitive, and modeling results from Ahmadov et al. (2015) suggest that the Uintah Basin regime is VOC-sensitive. Modeling results presented in Edwards et al. (2014) suggest that the dominant radical sources in the Uintah Basin are carbonyl compounds (85\%), with smaller inputs from $\mathrm{HONO}, \mathrm{O}_{3}$, and nitryl chloride $\left(\mathrm{ClNO}_{2}\right)$ photolysis.

Atmospheric measurements in the Uintah Basin during UBWOS2012, UBWOS2013, and UBWOS2014 reveal that the total reactive nitrogen abundances $\left(\mathrm{NO}_{y}\right.$ $=\mathrm{NO}+\mathrm{NO}_{2}+\mathrm{HNO}_{3}+\mathrm{PAN}+\mathrm{N}_{2} \mathrm{O}_{5}+\mathrm{NO}_{3}+\mathrm{ClNO}_{2}+$ organic nitrates) are highest (12-24 ppbv) in 2013 due to persistent shallow inversion layers triggered by stagnant air masses and snow cover, lowest in 2012 (4-9 ppbv) when no snow covered the ground, and in between $(8-18 \mathrm{ppbv})$ in winter 2014, with the highest $\mathrm{NO}_{y}$ values generally in midday (Wild et al., 2016). In 2013, $\mathrm{HNO}_{3}$ accounted for nearly half of total $\mathrm{NO}_{y}$, while in $2012 \mathrm{~N}_{2} \mathrm{O}_{5}$ and $\mathrm{ClNO}_{2}$ were larger components of total $\mathrm{NO}_{y}$ compared to $\mathrm{HNO}_{3}$ (Wild et al., 2016). Interestingly, atmospheric $\mathrm{NO}_{x}$ mixing ratios are similar in all three years, with diurnal averages ranging from $2 \mathrm{ppbv}$ during the night to $10 \mathrm{ppbv}$ during the day (Wild et al., 2016). The $\mathrm{NO}_{x} / \mathrm{NO}_{y}$ ratio, indicative of the rate of oxidation of reactive nitrogen, was highest in 2013 and lowest in 2012, with intermediate values in 2014 (Wild et al., 2016). $\mathrm{HO}_{2} \mathrm{NO}_{2}$ measurements range from 0 to $2.4 \mathrm{ppbv}$ in 2013 and $\sim 0$ to $0.4 \mathrm{ppbv}$ in 2014 (Veres et al., 2015) and are generally positively correlated with snow nitrite concentrations, suggesting that $\mathrm{HO}_{2} \mathrm{NO}_{2}$ deposition may be a source of snow nitrite (Veres et al., 2015).

In addition to aiding in the formation and maintenance of a stable air mass with enhanced UV radiation, snow may also recycle reactive nitrogen oxides $\left(\mathrm{N}_{\mathrm{r}}=\mathrm{NO}_{x}, \mathrm{HONO}\right)$ between the snow surface and the overlying atmosphere, effectively increasing the atmospheric lifetime of $\mathrm{N}_{\mathrm{r}}$. The major sink of $\mathrm{N}_{\mathrm{r}}$ in the atmosphere is the formation and deposition of nitrate (particulate $\mathrm{NO}_{3}^{-}$plus $\mathrm{HNO}_{3}(\mathrm{~g})$ ). When nitrate is deposited to snow, its photolysis serves to recycle $\mathrm{N}_{\mathrm{r}}$ to the overlying boundary layer (Grannas et al., 2007; Honrath et al., 2000). This snow-sourced $\mathrm{N}_{\mathrm{r}}$ can then be re-oxidized to nitrate and re-deposited to the snow surface. The recycling 
of nitrogen between the snow surface and boundary layer can occur many times, resulting in the continuous recycling of $\mathrm{N}_{\mathrm{r}}$ during sunlit conditions.

The photolysis of nitrate occurs in the liquid-like region (LLR) in or on ice grains (Domine et al., 2013) in the top snow layer where UV radiation is present, which is known as the snow photic zone. Snow nitrate photolyzes at wavelengths $(\lambda)=290-345 \mathrm{~nm}$ to produce aqueous-phase nitrogen dioxide $\left(\mathrm{NO}_{2}\right)$ or nitrite $\left(\mathrm{NO}_{2}^{-}\right)$according to Reactions (R1) and (R2) (Grannas et al., 2007; Mack and Bolton, 1999; Meusinger et al., 2014).

$\mathrm{NO}_{3}^{-}(\mathrm{aq})+h v\left(+\mathrm{H}^{+}\right) \rightarrow \mathrm{NO}_{2}(\mathrm{aq})+\mathrm{OH}(\mathrm{aq})$
$\mathrm{NO}_{3}^{-}(\mathrm{aq})+h v \rightarrow \mathrm{NO}_{2}^{-}(\mathrm{aq})+\mathrm{O}\left({ }^{3} \mathrm{P}\right)(\mathrm{aq})$

The measured quantum yields $(\phi)$ for Reaction (R1) range from 0.003 to 0.6 molec photon $^{-1}$ at $253 \mathrm{~K}$ (Chu and Anastasio, 2003; Meusinger et al., 2014; Zhu et al., 2010) and is likely influenced by the location of nitrate within ice grains. The $\mathrm{NO}_{2}$ produced in Reaction (R1) quickly evaporates due to its low solubility and can be transported to the overlying atmosphere. The nitrite produced in Reaction (R2) is rapidly photolyzed at longer wavelengths $(\lambda=290-390 \mathrm{~nm})$ (Reaction R3).

$\mathrm{NO}_{2}^{-}(\mathrm{aq})+h v\left(+\mathrm{H}^{+}, \mathrm{aq}\right) \rightarrow \mathrm{NO}(\mathrm{aq})+\mathrm{OH}(\mathrm{aq})$

Nitrite can also react with $\mathrm{OH}$ or $\mathrm{H}^{+}$in the LLR to produce aqueous-phase $\mathrm{NO}_{2}$ and $\mathrm{HONO}$ (Grannas et al., 2007):

$\mathrm{NO}_{2}^{-}(\mathrm{aq})+\mathrm{OH}(\mathrm{aq}) \rightarrow \mathrm{NO}_{2}(\mathrm{aq})+\mathrm{OH}^{-}(\mathrm{aq})$,

$\mathrm{NO}_{2}^{-}(\mathrm{aq})+\mathrm{H}^{+}(\mathrm{aq}) \rightarrow \mathrm{HONO}(\mathrm{aq})$.

HONO can rapidly photolyze in the LLR to produce aqueous-phase NO and $\mathrm{OH}$ (Anastasio and Chu, 2009); due to its short lifetime, the aqueous-phase $\mathrm{OH}$ remains in the LLR, but the aqueous-phase NO can be transferred to the gas phase and ultimately be released into the boundary layer. Under acidic conditions $\left(\mathrm{pk}_{\mathrm{a}}<2.8\right)$, aqueousphase HONO can also be transferred to the gas phase $(\mathrm{HONO}(\mathrm{aq}) \longleftrightarrow \rightarrow \mathrm{HONO}(\mathrm{g}))$ (Anastasio and $\mathrm{Chu}, 2009)$ and released into the boundary layer, where it can photolyze to produce gas-phase NO and $\mathrm{OH}$ (Zhou et al., 2001).

Nitrate nitrogen isotopes $\left(\delta^{15} \mathrm{~N}\left(\mathrm{NO}_{3}^{-}\right)\right)$in the air and snow can provide useful information about snow photochemistry, specifically, the degree of photolysis-driven recycling and loss of nitrate from the snow. Nitrogen isotope ratios are expressed as $\delta^{15} \mathrm{~N}$, where $\delta=R_{\text {sample }} / R_{\text {reference }}-1$, $R={ }^{15} \mathrm{~N} /{ }^{14} \mathrm{~N}$, and $\mathrm{N}_{2}$-air is the reference material. Nitrate photolysis in snow is a mass-dependent process and is associated with a large fractionation constant $(\varepsilon)$ of $-47.9 \%$ at wavelengths shorter than $320 \mathrm{~nm}$ (Berhanu et al., 2014). Nitrate photolysis provides the boundary layer with a source of $\mathrm{N}_{\mathrm{r}}$ that is highly depleted in ${ }^{15} \mathrm{~N}$, leaving highly enriched $\delta^{15} \mathrm{~N}\left(\mathrm{NO}_{3}^{-}\right)$deeper in the snow. Snow-sourced nitrate that is redeposited to the snow surface is lighter than the remaining nitrate in the snow, leading to $\delta^{15} \mathrm{~N}\left(\mathrm{NO}_{3}^{-}\right)$values that become more enriched with increasing depth within the snow photic zone. $\delta^{15} \mathrm{~N}\left(\mathrm{NO}_{3}^{-}\right)$values in the atmosphere are also influenced by the relative importance of different $\mathrm{NO}_{x}$ sources (see Felix and Elliott, 2014, for a summary). For example, the atmospheric $\delta^{15} \mathrm{~N}$ signature from anthropogenic $\mathrm{NO}_{x}$ sources, such as combustion of fossil fuels, ranges from -19.0 to $25.0 \%$ (Felix et al., 2012; Walters et al., 2015). The $\delta^{15} \mathrm{~N}$ signature from soil microbial activity is generally lower than that of anthropogenic activity and ranges from -50 to $-20 \%$ (Felix and Elliott, 2014). Observations of atmospheric $\delta^{15} \mathrm{~N}\left(\mathrm{NO}_{3}^{-}\right)$in non-polluted, mid-latitude regions range from -6 to $-2 \%$, while $\delta^{15} \mathrm{~N}\left(\mathrm{NO}_{3}^{-}\right)$values measured in polluted regions range from 0 to $6 \%$ (Morin et al., 2009). In addition, atmospheric $\delta^{15} \mathrm{~N}\left(\mathrm{NO}_{3}^{-}\right)$is influenced by $\mathrm{NO}_{x}$ cycling (Freyer et al., 1993; Walters et al., 2016), $\mathrm{NO}_{2}$ oxidation (Walters and Michalski, 2015), and the partitioning of nitrate between its gas and particulate phases (Heaton et al., 1997).

In this study, we investigate the importance of snow photochemistry as a source of reactive nitrogen oxides to the boundary layer in the Uintah Basin using chemical, isotopic, and optical measurements from the snow collected during the UBWOS 2014 campaign. In Sect. 2 we describe the field, laboratory, and modeling techniques used in this study. In Sect. 3 we present the chemical and optical measurements made during UBWOS 2014 and model-calculated fluxes of snow-sourced $\mathrm{N}_{\mathrm{r}}$. In Sect. 4 we estimate the contribution of snow-sourced $\mathrm{N}_{\mathrm{r}}$ to the $\mathrm{N}_{\mathrm{r}}$ burden in the Uintah Basin boundary layer.

\section{Methods}

\subsection{Field and laboratory observations}

\subsubsection{UBWOS 2014 field site description and meteorological conditions}

UBWOS 2014 occurred from 17 January to 13 February 2014 at the Horsepool field-intensive site $\left(40.1^{\circ} \mathrm{N}\right.$, $109.5^{\circ} \mathrm{W}$ ) in the Uintah Basin, roughly $55 \mathrm{~km}$ south of Vernal, Utah. There are over 10000 oil and natural gas wells in the basin connected by a series of dirt roads. The meteorological conditions were relatively constant for most of the campaign; wind speeds ranged from 1 to $3 \mathrm{~m} \mathrm{~s}^{-1}$ and often originated from the southwest. Sky conditions were clear, temperatures ranged from 258 to $275 \mathrm{~K}$, and boundary layer heights generally ranged from 25 to $150 \mathrm{~m}$. There were a few cloudy days (29 January-4 February, 10 February) during the campaign and the last several days experienced temperatures above freezing. Daily maximum boundary layer $\mathrm{O}_{3}$ mixing ratios ranged from 45 to $90 \mathrm{ppb}$, and the campaign-averaged daily-maximum boundary layer $\mathrm{O}_{3}$ mixing ratio was $61 \mathrm{ppb}$. 
Snow covered the ground throughout the duration of the campaign and ranged in depth from 10 to $30 \mathrm{~cm}$, depending on how snow was redistributed by wind after deposition. The snow was deep enough to cover some of the lowestlying vegetation, but branches from bushes were still visible. Three snow events occurred before the campaign, one event on 4 December, which deposited most of the snow $(19 \mathrm{~cm})$, and two smaller events on 8 and 19 December, which deposited roughly 3 and $1 \mathrm{~cm}$ of snow, respectively. There was a distinct crust layer roughly $4 \mathrm{~cm}$ below the snow surface, providing evidence of surface melting between the later two snowfall events. The temperature difference between the soil and the air was at least $15 \mathrm{~K}$ for several weeks, allowing vapor to redistribute through the snow, leading to the formation of large hoar crystals (radiation equivalent mean ice grain radii (Hansen and Travis, 1974) $\left(r_{\mathrm{e}}\right)>1200 \mu \mathrm{m}$ ) at all depths in the snow. There was one major snow event during the campaign from 30 through 31 January that deposited roughly $5 \mathrm{~cm}$ of fresh snow $\left(r_{\mathrm{e}} \sim 100 \mu \mathrm{m}\right)$. There were two smaller snow events on 4 and 10 February. On 4 February there was no measurable snow accumulation and during the early morning hours of 10 February there was $2 \mathrm{~cm}$ of fresh snow that subsequently melted several hours after sunrise. Figure S3b in the Supplement summarizes daily snow accumulation before and during the campaign.

\subsubsection{Snow pit measurements and snow sample preparation}

Twelve snow pits were dug approximately every 2 to 3 days during the campaign. Snow pits were dug from the snow surface to about $1 \mathrm{~cm}$ above the subniveal ground and ranged in depth from 9 to $24 \mathrm{~cm}$. The snow pits were dug in a variety of directions roughly $150 \mathrm{~m}$ from the main Horsepool site, except for snow pit 5 (24 January), which was dug roughly $800 \mathrm{~m}$ away from Horsepool. The snow pits were dug wearing clean, nitrate-free gloves using a stainless steel spatula. For each snow pit, vertical profiles ( $1 \mathrm{~cm}$ depth resolution) of snow density $\left(\rho_{\text {snow }}\right)$, temperature, and radiation equivalent ice grain radii $\left(r_{\mathrm{e}}\right)$ were measured using a Taylor-LaChapelle snow density kit, a dial stem thermometer, and a laminated snow grid card with $1 \mathrm{~mm}$ grid spacing, respectively. Snow grains from each distinct snow layer were placed on the snow grid card and a photograph was taken. The photographs were projected onto a larger screen and the shortest dimension of each snow crystal was estimated. The shortest dimension of a snow grain is the most optically important dimension (Grenfell and Warren, 1999), and in this study, it is used to represent $r_{\mathrm{e}}$. For hoar crystals, the smallest dimension is the width of the crystal wall and for freshly fallen crystals, the smallest dimension is the radius of the rounded crystal. For each snow pit, approximately $1 \mathrm{~kg}$ of snow was collected at $1 \mathrm{~cm}$ depth intervals and placed into Whirl-Pak plastic bags. The bags were kept covered while in the field and then immediately placed into a freezer once back at the Utah State University
(USU) Uintah Basin campus in Vernal, Utah. Section A in the Supplement shows detailed information on each snow pit.

\subsubsection{Optical measurements}

The snow from each plastic bag was spooned into a clean glass beaker and melted in a microwave oven at USU. The meltwater was transferred to a stainless steel funnel and passed through a $0.4 \mu \mathrm{m}$ Nuclepore filter, using an electric diaphragm vacuum pump to create a partial vacuum in a volumetric flask. The Nuclepore filter collects insoluble light absorbing impurities (LAI) in snow, including black carbon (BC) and non-black carbon (non-BC) species, the latter of which encompass brown carbon, dust, and organics. The volume of filtrate was measured, which ranged from 40 to 750 $\mathrm{ml}$ depending on impurity content. After the Nuclepore filters dried overnight, the filters were frozen until further analysis at the University of Washington (UW).

The absorption spectrum of each Nuclepore filter was measured using an ISSW spectrophotometer (Grenfell et al., 2011) in the Arctic Snow Laboratory at UW. The Nuclepore filter is placed between two integrating spheres lined with Spectralon material to create a fully diffuse medium. An Ocean Optics USB-650 spectrophotometer is used to measure the absorption spectrum in units of optical depth, $\tau(\lambda)$ (dimensionless, e.g., $\mathrm{cm}^{2} \mathrm{~cm}^{-2}$ ), from $\lambda=350-1000 \mathrm{~nm}$ in $10 \mathrm{~nm}$ intervals. A set of standard filters containing known loadings of black carbon (Fullerene) is used to calibrate the ISSW spectrophotometer. The spectral absorption measured by the spectrophotometer for each filter is characterized by an Ångström exponent $(\AA)$, which represents the total absorption by both $\mathrm{BC}$ and non-BC LAI on the filter between two visible wavelengths. $\AA$ is calculated in Eq. (1):

$\AA\left(\lambda_{1}\right.$ to $\left.\lambda_{2}\right)=\frac{\ln \left(\frac{\tau\left(\lambda_{1}\right)}{\tau\left(\lambda_{2}\right)}\right)}{\ln \left(\frac{\lambda_{2}}{\lambda_{1}}\right)}$,

where $\lambda_{1}=450 \mathrm{~nm}$ and $\lambda_{2}=600 \mathrm{~nm}$. The $\lambda=450-600 \mathrm{~nm}$ range is chosen because the ISSW spectrophotometer signal is most stable over this wavelength range. The total absorption Ångström exponent on each filter, along with assumed Ångström exponents for $\mathrm{BC}(\AA=1)$ and non-BC $(\AA=5)$, are used to estimate snow $\mathrm{BC}$ concentrations and the fraction of ultraviolet $(\lambda=300-350 \mathrm{~nm})$ absorption by non-BC material (see Doherty et al., 2010; Grenfell et al., 2011; Zatko et al., 2013; Zatko and Warren, 2015). Triplicate measurements were performed for all samples.

Surface upwelling and downwelling irradiance was measured using a commercial spectral radiometer equipped with a photodiode array (Metcon $\mathrm{GmbH} \&$ Co. KG, http: //www.metcon-us.com). Upwelling and downwelling UVA and UV-B were measured with Kipp and Zonen Model UV-S-AB-T radiometers. Radiometers were placed at $2 \mathrm{~m}$ above ground (one up-facing and one down-facing) and were cleaned and checked weekly to ensure that the radiometers 
remained directly perpendicular to the ground. Detailed irradiance data are provided in the Supplement.

\subsubsection{Chemical concentration and nitrate isotopic measurements}

In a laboratory on the USU campus in Vernal, UT, a $50 \mu \mathrm{L}$ aliquot of snow meltwater that was passed through the $\mathrm{Nu}$ clepore filter was used to measure ion $\left(\mathrm{Cl}^{-}, \mathrm{Br}^{-}, \mathrm{NO}_{3}^{-}\right.$, $\mathrm{SO}_{4}^{2-}, \mathrm{Na}^{+}, \mathrm{NH}_{4}^{+}, \mathrm{K}^{+}, \mathrm{Mg}^{+2}, \mathrm{Ca}^{+2}$, oxalate) concentrations using a Metrohm 761 Compact Ion Chromatograph Analyzer (Quinn et al., 1998). The nitrate in the remaining filtrate was pre-concentrated for isotopic analysis. Nitrate was pre-concentrated by passing the meltwater through an anion exchange resin (Bio-Rad AG 1-X8) using an electric diaphragm pump. The sample anions in the resin were eluted with $5 \times 2 \mathrm{~mL} 1 \mathrm{M}$ sodium chloride ( $\mathrm{NaCl} / \mathrm{Milli}-\mathrm{Q}$ water) solution into a $30 \mathrm{~mL}$ pre-cleaned sample bottle. This method has been shown to ensure full recovery of nitrate (Silva et al., 2000; Frey et al., 2009) The solution was kept frozen in the dark until analysis in the University of Washington IsoLab (http://isolab.ess.washington.edu/isolab/).

The denitrifier method (Casciotti et al., 2002; Kaiser et al., 2007; Sigman et al., 2001) was used to determine the nitrogen isotopic signature $\left(\delta^{15} \mathrm{~N}\right)$ in each snow sample. Denitrifying bacteria, Pseudomonas aureofaciens, convert nitrate to nitrous oxide $\left(\mathrm{N}_{2} \mathrm{O}\right)$ gas in anaerobic conditions (Casciotti et al., 2002; Sigman et al., 2001), and $\mathrm{N}_{2} \mathrm{O}$ is transported via helium gas through a heated gold tube $\left(800^{\circ} \mathrm{C}\right)$, where it thermally decomposes into $\mathrm{O}_{2}$ and $\mathrm{N}_{2}$. After separation by gas chromatography, the $\mathrm{O}_{2}$ and $\mathrm{N}_{2}$ are run through a Thermo Finnigan ${ }^{\mathrm{TM}}$ Delta Plus Advantage isotope ratio mass spectrometer (IRMS), equipped with a Precon and GasBench $\mathrm{II}^{\mathrm{TM}}$. The $\delta^{15} \mathrm{~N}$ values were calculated with respect to $\mathrm{N}_{2}$ (air) via two international reference materials, USGS32 $\left(\delta^{15} \mathrm{~N}=180 \% \circ\right)$ and USGS34 $\left(\delta^{15} \mathrm{~N}=-1.8 \% \circ\right)$, with IAEA $\left(\delta^{15} \mathrm{~N}=4.7 \%\right.$ ) as a quality control standard. For many samples, the $\mathrm{NaCl} / \mathrm{NO}_{3}^{-}$solution was diluted with Milli-Q water to obtain the optimal nitrate concentration $(200 \mathrm{nmol}$ in $2 \mathrm{~mL}$ ) for each sample run on the IRMS. Triplicate measurements were performed for all samples. The analytical uncertainty of $\delta^{15} \mathrm{~N}\left(\mathrm{NO}_{3}^{-}\right)(1 \sigma)$ was $0.75 \%$ o based on repeated measurements of the quality control standard.

Aerosol nitrate was collected throughout the campaign in $12 \mathrm{~h}$ intervals. Aerosol nitrate was sampled from an inlet $13 \mathrm{~m}$ above ground and drawn through a heated $(283 \mathrm{~K})$ pipe, where it was then collected on a two-stage, multi-jet cascade impactor. The impactor Tedlar films separates aerosols with diameters less than $2.5 \mu \mathrm{m}$ from those with diameters between 2.5 and $12.5 \mu \mathrm{m}$. The aerosols were extracted from the filters and analyzed using ion chromatography, following methods described in Quinn et al. (2000). Gas-phase nitric acid was measured using an Acetate HR-ToF-CIMS instrument throughout the campaign with 1 min time resolution, as described in Yuan et al. (2016).

\subsection{Calculations}

\subsubsection{Snow radiative transfer model}

A four-stream, plane-parallel radiative transfer model using the discrete ordinates method with a $\delta$-M transformation originally described in Grenfell (1991) was used to calculate vertical profiles of UV actinic flux in each snow pit. This model properly treats layers with differing refractive indices and the 4-stream model produces albedo and absorptivity results that agree to within $1 \%$ of higher-order models representative of snow (Wiscombe, 1977), including DISORT (Stamnes et al., 1988). Vertical profiles of the $\rho_{\text {snow }}, r_{\mathrm{e}}$, and LAI absorption are used to calculate vertical profiles of inherent optical properties (IOPs) in snow at the wavelengths relevant for photochemistry (UV). These wavelength-dependent IOPs include the bulk extinction coefficient in snow $\left(K_{\text {ext } t_{\text {tot }}}\right)$ and the co-albedo of single scattering ( $\left.c \varpi_{\text {eff }}\right)$; see Zatko et al. (2013) for more details about the IOP calculations. $K_{\text {ext }}$ and $c \varpi_{\text {eff }}$, along with observations of downwelling surface UV irradiance, solar zenith angle, cloud fraction, and soil albedo (0.1) (Markvart and Castalzer, 2003; Matthias et al., 2000), are used to calculate $1 \mathrm{~cm}$ resolution vertical profiles of UV actinic flux for each snow pit, following methods described in Zatko et al. (2013). The UV actinic flux profiles are used to calculate depth-dependent photolysis rate constants for nitrate photolysis in snow as described below.

\subsubsection{Snow-sourced reactive nitrogen flux calculations}

The modeled vertical profiles of actinic flux and observed snow nitrate concentrations are used to calculate dailyaverage fluxes of snow-sourced $\mathrm{N}_{\mathrm{r}}$ from each snow pit according to Eq. (2).

$$
\begin{aligned}
F_{\mathrm{N}_{\mathrm{r}}}(z) & =\int_{\lambda_{0}}^{\lambda_{1}} \sigma_{\mathrm{NO}_{3}^{-}}(\lambda) \cdot \phi(T, \mathrm{pH}) \cdot I(\lambda, z) \\
& \cdot\left[\mathrm{NO}_{3}^{-}\right](z) \mathrm{d} \lambda
\end{aligned}
$$

$F_{\mathrm{N}_{\mathrm{r}}}(z)$ is the flux of snow-sourced $\mathrm{N}_{\mathrm{r}}\left(\right.$ molec cm $\left.\mathrm{cm}^{-2} \mathrm{~s}^{-1}\right)$ at $1 \mathrm{~cm}$ depth $(z)$ increments in the snow, $\sigma_{\mathrm{NO}_{3}}^{-}$is the wavelength $(\lambda)$-dependent absorption crosssection for nitrate photolysis $\left(\mathrm{cm}^{2}\right)$ from Berhanu et al. (2014), $\phi$ is the temperature- and $\mathrm{pH}$-dependent quantum yield for nitrate photolysis $\left(\phi\right.$, molec photon $\left.{ }^{-1}\right)$ from Chu and Anastasio (2003) $\left(4.6 \times 10^{-3}\right.$ molec photon $^{-1}$ at $\left.T=267 \mathrm{~K}\right), I$ is the depth (z)- and $\lambda$-dependent actinic flux in the snow photic zone (photons $\mathrm{cm}^{-2} \mathrm{~s}^{-1} \mathrm{~nm}^{-1}$ ), and $\left[\mathrm{NO}_{3}^{-}\right](z)$ is the observed nitrate concentration $\left(\mathrm{ng} \mathrm{g}^{-1}\right)$ in each snow layer. Equation (2) is integrated over the UV wavelength region $(\lambda=298-345 \mathrm{~nm})$. The snow photic zone is defined as 3 times the $e$-folding depth of UV actinic flux in snow (Zatko et al., 2016). The total flux of $\mathrm{N}_{\mathrm{r}}$ to the boundary layer, 
$F_{\mathrm{N}_{\mathrm{r}}}$, is calculated according to Eq. (3).

$F_{\mathrm{N}_{\mathrm{r}}}=\sum_{z_{0}}^{z_{3 e}} F_{\mathrm{N}_{\mathrm{r}}}(z)$

Observed surface downwelling irradiance values for a solar zenith angle of $65^{\circ}$, the average solar zenith angle from mid-December to mid-February, are used for calculation of $I(\lambda, z)$ in Eq. (3). Therefore the calculated $F_{\mathrm{N}_{\mathrm{r}}}$ values represent daily averaged $F_{\mathrm{N}_{\mathrm{r}}}$ values. It is assumed that all $\mathrm{N}_{\mathrm{r}}$ escapes into the boundary layer due to its low solubility.

\subsubsection{Snow photochemistry column model (TRANSITS)}

The flux of snow-sourced $\mathrm{N}_{\mathrm{r}}$ from each snow pit is also calculated using a snow photochemistry column model, TRansfer of Atmospheric Nitrate Stable Isotopes To the Snow (TRANSITS)(Erbland et al., 2015). TRANSITS is a multilayer, one-dimensional model that simulates nitrate photochemistry in the snow and allows for chemical exchange between the air and snow and calculates the isotopic composition of snow nitrate. The model was originally developed to simulate snow nitrate photolysis and subsequent nitrogen recycling at the air-snow interface on the eastern Antarctic Plateau (Dome C), and has been adapted to mid-latitude, shallow-snowpack conditions for this study. The model has a well-mixed, atmospheric boundary layer with a height of $50 \mathrm{~m}$ and a snow compartment containing up to fifty $1 \mathrm{~cm}$ thick layers. In the atmosphere and in each snow layer, the model solves a general mass-balance equation for nitrate concentration and isotopic composition (Erbland et al., 2015) at each time step $(1 \mathrm{~h})$.

In TRANSITS, nitrate is deposited to the snow surface via dry deposition. Nitrate dry deposition is calculated using the campaign-averaged observed boundary layer mixing ratios for $\mathrm{HNO}_{3}\left(5784 \mathrm{ng} \mathrm{m}^{-3}\right)$ and $\mathrm{NO}_{3}^{-}\left(5777 \mathrm{ng} \mathrm{m}^{-3}\right)$, and an assumed dry-deposition velocity of $0.03 \mathrm{~cm} \mathrm{~s}^{-1}$, which is similar to the dry-deposition velocity used in Edwards et al. $(2013,2014)\left(0.02 \mathrm{~cm} \mathrm{~s}^{-1}\right)$ (see Table $1 \mathrm{~B}$ in the Supplement for nitrate dry-deposition fluxes). Nitrate diffuses through the snowpack based on a diffusion coefficient that is dependent on temperature, pressure, snow specific surface area, snow density, and tortuosity (Crowley et al., 2010; Durham and Stockburger, 1986; Massman, 1998).

We include only the major channel for the production of $\mathrm{N}_{\mathrm{r}}$ from nitrate photolysis (Reaction R1) in TRANSITS. The minor channels, Reactions (R2)-(R5), all consist of chemistry of the intermediate in nitrate photolysis, i.e., nitrite, which will photolyze or react rapidly once produced to form $\mathrm{N}_{\mathrm{r}}$. We assume no export of snow-sourced $\mathrm{N}_{\mathrm{r}}$ out of the atmospheric box, which is consistent with the low wind speeds and stable boundary layer conditions observed during the campaign. In this way there is no net loss of nitrate from the snow; however, vertical redistribution of snow nitrate can occur, which would result in distinctive vertical profiles of nitrate concentration and $\delta^{15} \mathrm{~N}\left(\mathrm{NO}_{3}^{-}\right)$in the snow column. In addition to calculating the flux of snow-sourced $\mathrm{N}_{\mathrm{r}}$, TRANSITS calculates vertical profiles of nitrate concentration and isotopes $\left(\delta^{15} \mathrm{~N}\left(\mathrm{NO}_{3}^{-}\right)\right)$in the snow. To calculate $\delta^{15} \mathrm{~N}\left(\mathrm{NO}_{3}^{-}\right)$in the snow, the nitrate photolysis fractionation factor $\left({ }^{15} \varepsilon_{\text {pho }}\right)$ is calculated at each time step and is dependent upon the spectral distribution of the UV irradiance at the snow surface (Bernhau et al., 2014; Erbland et al., 2015). Calculated ${ }^{15} \varepsilon_{\text {pho }}$ values range from -88 to $-35 \%$ o between the snow pits and are constant with snow depth.

In this study, TRANSITS is run at hourly resolution and is spun up beginning 27 days before the start of the campaign using available atmospheric chemical (boundary layer, gasphase, and aerosol-phase nitrate) and meteorological data (air, temperature, and pressure). A constant model boundary layer height of $50 \mathrm{~m}$ is assumed, which is a rough estimate of daily averaged boundary layer heights based on sodar facsimile data from NOAA. The campaign-averaged observed boundary layer total nitrate $\left(\mathrm{HNO}_{3}+\mathrm{NO}_{3}^{-}\right)$mixing ratio $\left(11.56 \mathrm{~g} \mathrm{~m}^{-3}\right)$ was used to spin up the model. We collected and measured atmospheric $\delta^{15} \mathrm{~N}\left(\mathrm{NO}_{3}^{-}\right)$throughout the campaign using a high-volume air sampler with Nylasorb filters. However, comparison with the aerosol nitrate $\left(\mathrm{NO}_{3}^{-}\right.$) concentration measurements from the PMEL (Pacific Marine Environmental Laboratory) two-stage, multi-jet cascade impactor measurements revealed incomplete trapping. Since non-quantitative collection of nitrate may influence the observed $\delta^{15} \mathrm{~N}\left(\mathrm{NO}_{3}^{-}\right)$values, the data were not used in this study. We instead use surface snow $\delta^{15} \mathrm{~N}\left(\mathrm{NO}_{3}^{-}\right)$observations to represent atmospheric $\delta^{15} \mathrm{~N}\left(\mathrm{NO}_{3}^{-}\right)$(Fig. 1a). The TRANSITS snowpack is initialized by setting the snow height equal to $50 \mathrm{~cm}$, the snow photic zone to $6 \mathrm{~cm}$ (average photic zone depth for all snow pits), and using the measured snow nitrate concentration and $\delta^{15} \mathrm{~N}\left(\mathrm{NO}_{3}^{-}\right)$vertical profiles from the first snow pit of the campaign ( 15 January). The snowfall event on 31 January is simulated in the model, but the other smaller events are not included. As the model evolves, "snapshots" of the top $25 \mathrm{~cm}$ of snow are taken on days corresponding to each snow pit, and modeled profiles of nitrate concentration and $\delta^{15} \mathrm{~N}\left(\mathrm{NO}_{3}^{-}\right)$are compared to observed profiles for each snow pit. Since vertical profiles of snow $\delta^{15} \mathrm{~N}\left(\mathrm{NO}_{3}^{-}\right)$ are highly sensitive to photochemical-driven redistribution of $\mathrm{N}_{\mathrm{r}}$ in the snowpack (Erbland et al., 2013, 2015), observed $\delta^{15} \mathrm{~N}\left(\mathrm{NO}_{3}^{-}\right)$provides a metric to assess model-calculated $F_{\mathrm{N}_{\mathrm{r}}}$. 

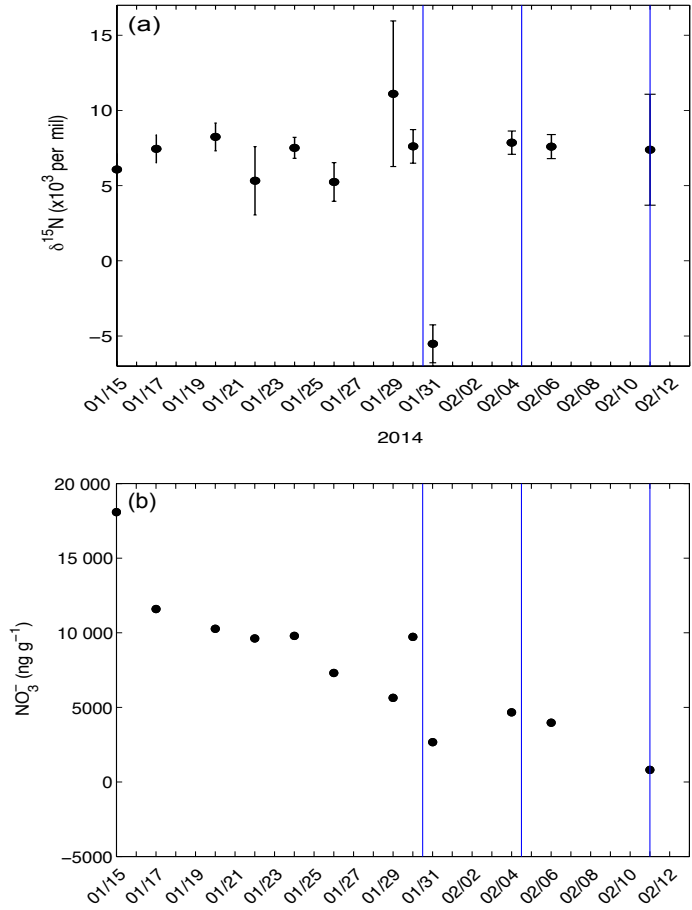

Figure 1. (a) Mean surface snow (top $1 \mathrm{~cm}) \delta^{15} \mathrm{~N}\left(\mathrm{NO}_{3}^{-}\right)$observations $(\% \circ)$ for triplicate measurements from each snow pit (close circles). The full range of triplicate measured surface snow $\delta^{15} \mathrm{~N}\left(\mathrm{NO}_{3}^{-}\right)$for each snow pit is also indicated (vertical black lines). (b) Surface snow nitrate concentration measurements $\left(\mathrm{ng}^{-1}\right)$ for each snow pit. The uncertainty in the concentration measurements is $0.75 \%$. The vertical blue lines indicate snowfall events.

\section{Results and discussion}

\subsection{Observations}

\subsubsection{Nitrate concentrations and $\delta^{15} \mathrm{~N}\left(\mathrm{NO}_{3}^{-}\right)$in the surface snow}

Figure 1a shows mean surface snow $\delta^{15} \mathrm{~N}\left(\mathrm{NO}_{3}^{-}\right)$values for each snow pit, which range from -5.5 to $11.1 \%$. The lowest observed surface snow $\delta^{15} \mathrm{~N}\left(\mathrm{NO}_{3}^{-}\right)$occurred immediately after the only significant fresh snowfall event on 30-31 January $(-5.5 \%)$. All other surface snow samples were over $10 \%$ o higher (5.2 to $11.1 \%$ ).

Figure $1 \mathrm{~b}$ shows surface snow nitrate concentration measurements for each snow pit, which range from 800 to $18000 \mathrm{ng} \mathrm{g}^{-1}$. Similar to $\delta^{15} \mathrm{~N}\left(\mathrm{NO}_{3}^{-}\right)$, surface-snow nitrate concentrations are lowest during the snowfall event on 3031 January, with the exception of 11 February when the snow was rapidly melting. Similarly, boundary layer gas $\left(\mathrm{HNO}_{3}\right)$ and aerosol-phase $\left(\mathrm{NO}_{3}^{-}\right)$nitrate mixing ratios decrease by a factor of 6 between 30 and 31 January (Fig. S1b in the Supplement) compared to the rest of the field campaign. In addition to the gas and aerosol phase nitrate mixing ratios presented in the Supplement, Veres et al. (2015) also show decreases in the daily maximum $\mathrm{HO}_{2} \mathrm{NO}_{2}$ mixing ratios on 30 and 31 January during UBWOS2014. The decrease in $\mathrm{HO}_{2} \mathrm{NO}_{2}$ mixing ratios corresponds to a sharp decrease in snow nitrite concentrations (see Fig. 7 in Veres et al., 2015).

Generally, the surface-snow $\delta^{15} \mathrm{~N}\left(\mathrm{NO}_{3}^{-}\right)$values fall within the range of primary anthropogenic $\delta^{15} \mathrm{~N}$ values $(4-25 \%$ ) (Felix and Elliott, 2014; Walters et al., 2015). During snow events the boundary layer is less stable, possibly allowing for the transport of nitrate from remote sources outside the basin. In unpolluted, mid-latitude environments, background atmospheric $\delta^{15} \mathrm{~N}\left(\mathrm{NO}_{3}^{-}\right)$ranges from -6 to $-2 \%$ (Morin et al., 2009). During the major snowfall event on 30-31 January, surface-snow $\delta^{15} \mathrm{~N}$ values were $\sim 10 \%$ o lower compared to the rest of the campaign, suggesting that nitrate from beyond the basin deposits to the snow surface. Two-day NOAA HYSPLIT back trajectories (Rolph, 2016; Stein et al., 2015) show that the air mass on 31 January in the Uintah Basin originated in the Pacific Ocean, which is distinctly different from the other air masses that reached the Uintah Basin during UBWOS2014 (see Supplement, Figs. S4b-S15b). Uintah Basin boundary layer air masses typically originated in the inter-mountain western region and often centered over eastern Utah for several days.

\subsubsection{Snow depth profiles of snow optical properties, nitrate concentrations, and $\delta^{15} \mathrm{~N}\left(\mathrm{NO}_{3}^{-}\right)$}

In this section and the following sections, we focus on three snow pits (22, 31 January, and 4 February) as being representative of the time period before, during, and after the largest snow event. The other nine snow pits will not be discussed in detail, but observed and modeled vertical profiles of chemical and optical measurements for all 12 snow pits can be found in the Supplement Sect. A.

Figure $2 \mathrm{a}$ and $\mathrm{b}$ show vertical profiles of snow optical properties from an $18 \mathrm{~cm}$ deep snow pit dug on 22 January, which represents typical profiles from the beginning of the field campaign until before the first snow event. Black carbon concentrations $\left(C_{\mathrm{BC}}, \mathrm{ng} \mathrm{g}^{-1}\right)$ range from 3 to $100 \mathrm{ng} \mathrm{g}^{-1}$ with the highest concentrations in the top several centimeters of snow. Below $3 \mathrm{~cm}$ snow depth, $C_{\mathrm{BC}}$ decreases dramatically. Figure $2 b$ shows the average absorption Ångström exponent $(\AA)$ from $\lambda=450-600 \mathrm{~nm}$. Over this wavelength range, the dominant absorber at the snow surface is non-BC material ( $\AA$ is nearly 5$)$, and both $\mathrm{BC}$ and non-BC contribute to absorption in sub-surface snow layers $(\AA$ ranges from 2 to 2.7). Although $\mathrm{BC}$ and non-BC material are both responsible for the absorption of radiation at $\lambda=450-600 \mathrm{~nm}$, nonBC material is responsible for between 99.6 and $100 \%$ of $\mathrm{UV}(\lambda=300-350 \mathrm{~nm})$ absorption at all depths in this and all snow pits measured during the field campaign. The top $3 \mathrm{~cm}$ of snow contains the highest concentration of both $\mathrm{BC}$ and non-BC material; we define this layer as the "dusty layer" and it is represented as a brown shaded region in Fig. 2. 

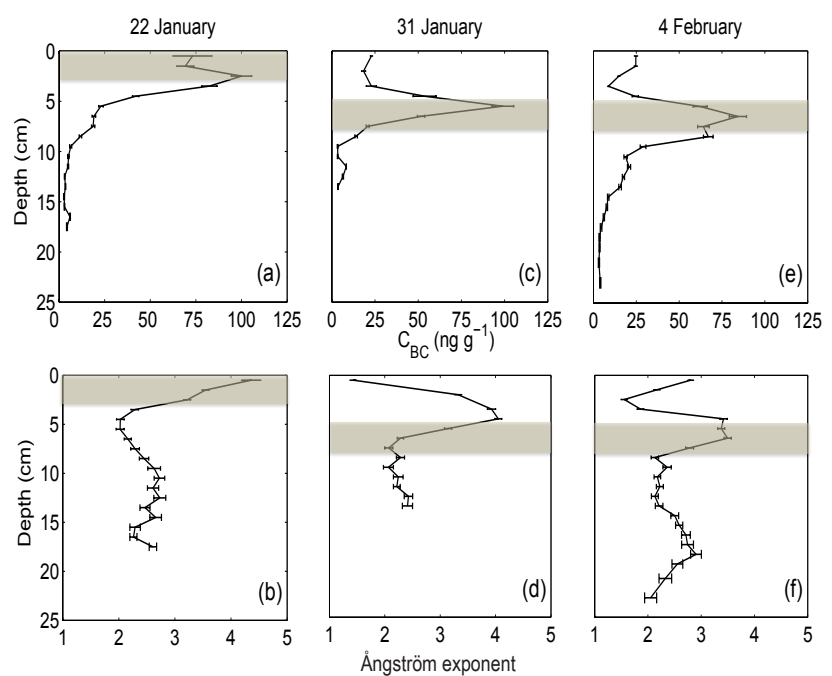

Figure 2. Snow optical properties measured on 22 January (left), 31 January (middle), and 4 February (right). (top) Vertical profiles of mean snow black carbon $\left(C_{\mathrm{BC}}, \mathrm{ng} \mathrm{g}^{-1}\right)$ measurements and the full range of $C_{\mathrm{BC}}$ measured at each depth (horizontal black lines), (bottom) mean Angström exponent ( $\AA$, unitless) measurements and the full range of $\AA$ measured at each depth (horizontal black lines). The brown shaded region represents the dusty layer as defined in the text.

Figure 2c and d show vertical profiles of snow optical properties from a $14 \mathrm{~cm}$ deep snow pit dug on 31 January. It snowed $5 \mathrm{~cm}$ between the afternoon of 30 January and the morning of 31 January, and this new snow layer is evident in Fig. 2c and d because the dusty layer is now located roughly $5 \mathrm{~cm}$ below the snow surface. Figure 2c shows that $C_{\mathrm{BC}}$ ranges from 5 to $100 \mathrm{ng} \mathrm{g}^{-1}$; the maximum $C_{\mathrm{BC}}$ value has been buried deeper in the snow. Figure $2 \mathrm{~d}$ shows that $\AA$ is close to 1 at the snow surface, indicating that BC material dominates visible absorption at the snow surface immediately following the fresh snowfall event. Figure $2 \mathrm{e}$ and $\mathrm{f}$ show vertical profiles of snow optical properties from a $24 \mathrm{~cm}$ deep snow pit dug on 4 February, 5 days after the snow event. In this snow pit, $C_{\mathrm{BC}}$ ranges from 4 to $100 \mathrm{ng} \mathrm{g}^{-1}$ and $\AA$ ranges from 1.7 to 3.4 . Figure $2 \mathrm{e}$ and $\mathrm{f}$ show that the original dusty layer is still located roughly $5 \mathrm{~cm}$ below the snow surface and that a new dusty layer has formed at the snow surface.

Figure $3 a-c$ show observed vertical profiles of nitrate in snow from snow pits dug on 22, 31 January, and 4 February. Prior to the fresh snowfall event, snow nitrate concentrations were highest at the surface (13900 $\left.\mathrm{ng} \mathrm{g}^{-1}\right)$, and decreased exponentially in the top $10 \mathrm{~cm}$ to a low of $90 \mathrm{ng} \mathrm{g}^{-1}$ at $18 \mathrm{~cm}$ depth (Fig. 3a). Immediately following the fresh snowfall event, the highest nitrate concentrations (12 200 $\mathrm{ng} \mathrm{g}^{-1}$ ) are buried below $5 \mathrm{~cm}$ of fresh snow within the dusty layer at 5$7 \mathrm{~cm}$ depth. The measured nitrate concentrations in the fresh snow layer range from 1280 to $4640 \mathrm{ng} \mathrm{g}^{-1}$, which is up to 10 times lower than nitrate concentrations in the dusty layer (Fig. 3b). Five days after the fresh snowfall event, the highest

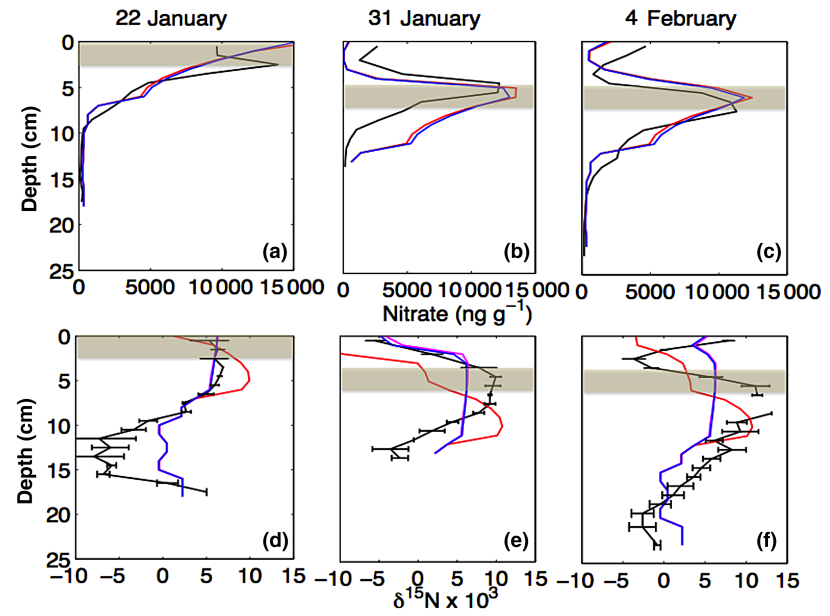

Figure 3. Measured (black) and modeled $\left(\Phi=4.6 \times 10^{-3}\right.$, blue; $\Phi=0.2$, red) vertical profiles of snow nitrate concentration (top) and $\delta^{15} \mathrm{~N}\left(\mathrm{NO}_{3}^{-}\right)$(bottom) on 22 January (left), 31 January (center), and 4 February (right). Modeled $\delta^{15} \mathrm{~N}\left(\mathrm{NO}_{3}^{-}\right)$profiles are calculated using variable quantum yields $\left(\Phi=4.6 \times 10^{-3}\right.$, blue; $\Phi=0.2$, red; $\Phi=0$, magenta). The brown shaded region represents the dusty layer.

nitrate concentrations are still located roughly $7 \mathrm{~cm}$ below the snow surface within the dusty layer, but surface nitrate concentrations are a factor of 2 higher compared to immediately after the fresh snowfall event (Fig. 3c).

Figure $3 \mathrm{~d}-\mathrm{f}$ show measured snow $\delta^{15} \mathrm{~N}\left(\mathrm{NO}_{3}^{-}\right)$in each of the snow pits, which ranges from -5.5 to $13 \%$. In the 22 January snow pit, measured $\delta^{15} \mathrm{~N}\left(\mathrm{NO}_{3}^{-}\right)$is highest near the top and bottom of the snow pit and lowest from 12 to $16 \mathrm{~cm}$ depth (Fig. 3d). Following the fresh snowfall event on 30-31 January, snow $\delta^{15} \mathrm{~N}\left(\mathrm{NO}_{3}^{-}\right)$values are lowest at the snow surface and increase with depth in the fresh snow layer until the top of the dusty layer, below which they decrease to $-3.5 \%$ (Fig. 3e). Five days after the fresh snowfall event, measured $\delta^{15} \mathrm{~N}\left(\mathrm{NO}_{3}^{-}\right)$is most enriched in the dusty layer and at the snow surface (Fig. 3f).

The last snowfall event prior to the start of the campaign occurred on 19 December and resulted in roughly $1 \mathrm{~cm}$ of snow accumulation (Supplement Fig. S5a). The high concentrations of LAI and nitrate in surface snow on 22 January, combined with the prolonged lack of snowfall, suggest continual dry-deposition of LAI to the surface snow. We speculate that the major source of LAI originates from truck traffic on the dirt roads in the area of the field site due to high values of $\AA$ (Fig. 2). The factor of 150 and 17 decrease in nitrate and black carbon concentrations, respectively, from the surface to $18 \mathrm{~cm}$ depth on 22 January suggests that minimal nitrate and LAI are transported (via, e.g., diffusion or meltwater transport) from upper to lower snow layers. Immediately after the snowfall event on 31 January, nitrate and black carbon concentrations are 10 and 3 times lower, respectively, in the sur- 
face snow layers compared to earlier in January, because the fresh snow has lower concentrations of these species. Even just five days after the snowfall event on 30-31 January, concentrations of nitrate and the Ångström exponent $(\AA)$ in the snow surface layer have increased by a factor of 2 , which is likely due to dry deposition of these species to the surface in the absence of snowfall.

The $\delta^{15} \mathrm{~N}\left(\mathrm{NO}_{3}^{-}\right)$profiles in snow do not immediately suggest significant photolysis-driven redistribution of nitrate in the snowpack, which would result in the lowest values at the surface, increasing exponentially with depth as observed in Antarctica (Erbland et al., 2013). Prior to the first snowfall event on 30-31 January, the surface dusty layer contains the highest values of measured $\delta^{15} \mathrm{~N}\left(\mathrm{NO}_{3}^{-}\right)$, which are similar to those expected from primary emission of $\mathrm{NO}_{x}$ from anthropogenic sources (Felix and Elliott, 2014; Walters et al., 2015). We speculate that the depleted $\delta^{15} \mathrm{~N}\left(\mathrm{NO}_{3}^{-}\right)$values towards the bottom of the snow pit correspond to remotesourced atmospheric nitrate that was deposited during the large snow event ( $\sim 20 \mathrm{~cm}$ of snow) on 4 December. Emissions of microbial NO from subniveal soil could also lead to depleted $\delta^{15} \mathrm{~N}\left(\mathrm{NO}_{3}^{-}\right)$if this $\mathrm{NO}$ is oxidized to nitrate in the snowpack and deposited to the surface of snow grains before escaping to the atmosphere. However, the depleted $\delta^{15} \mathrm{~N}\left(\mathrm{NO}_{3}^{-}\right)$would also likely correspond with enhanced nitrate concentrations, which is not observed (Fig. 3a-c). Additionally, calculations by Zatko et al. (2013) suggest that the lifetime of $\mathrm{NO}_{x}$ against oxidation to $\mathrm{HNO}_{3}$ in snow interstitial air is long enough so that most NO emitted from soil microbial activity would likely be transported to the atmospheric boundary layer prior to oxidation. On 31 January, depleted $\delta^{15} \mathrm{~N}\left(\mathrm{NO}_{3}^{-}\right)$measurements at the snow surface suggest that there is deposition of nitrate from less polluted regions surrounding the basin during the snow event. The increase in surface snow $\delta^{15} \mathrm{~N}\left(\mathrm{NO}_{3}^{-}\right)$values after 31 January is likely due to deposition of primary-sourced nitrate from anthropogenic $\mathrm{NO}_{x}$ sources in the basin. In the following section, we examine the influence of photolysis of snow nitrate on the profiles of $\delta^{15} \mathrm{~N}\left(\mathrm{NO}_{3}^{-}\right)$in snow.

\subsection{Calculations}

\subsubsection{Calculations of snow actinic flux profiles and flux of snow-sourced $\mathrm{N}_{\mathbf{r}}$}

Figure $4 \mathrm{a}-\mathrm{c}$ show calculated vertical profiles of UV actinic flux normalized to surface downwelling irradiance for the three snow pits. On 22 January, the normalized actinic flux ratio is nearly 4 at the snow surface because actinic flux is calculated by integrating irradiance over a sphere (surface area of $4 \pi r^{2}$ ) and also because scattering in snow dominates over absorption. In Fig. 4a, the actinic flux decreases to 2.9 within the top centimeter of snow due mainly to UV absorption by non-BC in the surface snow layer. The actinic flux is rapidly extinguished in the dusty layer and contin-

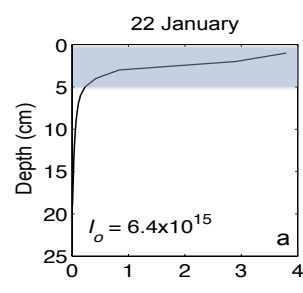

31 January
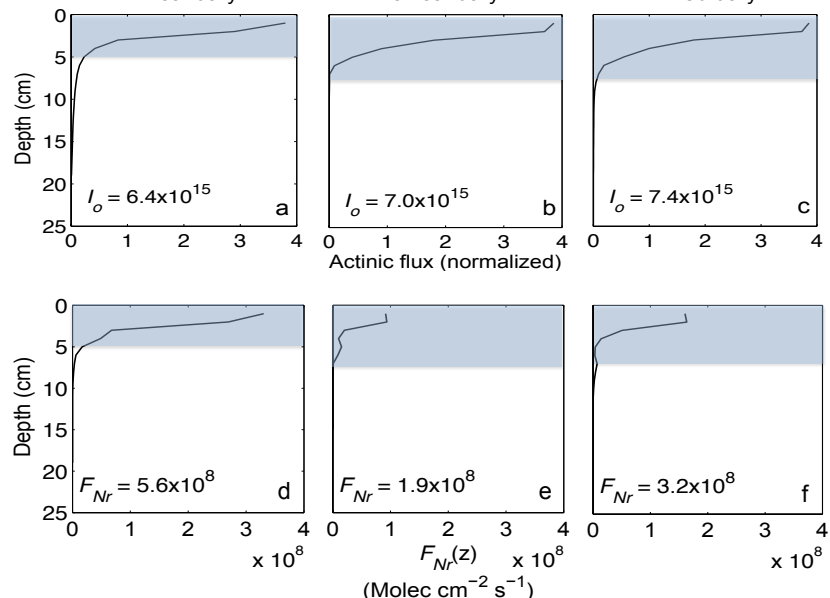

Figure 4. (a-c) Modeled vertical profiles of UV actinic flux ( $I$, photons $\mathrm{cm}^{-2} \mathrm{~s}^{-1}$ ) normalized to surface downwelling irradiance $\left(I_{O}\right.$, photons $\left.\mathrm{cm}^{-2} \mathrm{~s}^{-1}\right)$. Also presented is measured total $\mathrm{UV} I_{O}$ $(\lambda=300-350 \mathrm{~nm})$ for a solar zenith angle of $60^{\circ}$ on each day. (d-f) Modeled vertical profiles of snow-sourced $\mathrm{N}_{\mathrm{r}}$ fluxes $\left(F_{\mathrm{N}_{\mathrm{r}}}\right.$, molec $\mathrm{cm}^{-2} \mathrm{~s}^{-1}$ ) calculated using Eq. (3). Also shown is total $F_{\mathrm{N}_{\mathrm{r}}}$, which is the depth-integrated $F_{\mathrm{N}_{\mathrm{r}}}$ over the photic zone. The blue shaded region represents the snow photic zone.

ues to decrease with increasing snow depth, reaching a value of 0.01 at $18 \mathrm{~cm}$ depth. The blue shaded region represents the snow photic zone (top $5 \mathrm{~cm}$ of snow) on 22 January. The snow photic zones calculated in this study $(4-7 \mathrm{~cm})$ are much shallower compared to calculated snow photic zones in polar regions (72-207 cm in Antarctica, 6-51 cm in Greenland) (Zatko et al., 2016) because UV absorption by LAI in the snow photic zone is at least 5 orders of magnitude higher in Utah compared to Antarctica and Greenland.

In the snow pits following the fresh snowfall event, the existence of the dusty layer deeper in the snow influences the vertical actinic flux profile and increases the photic zone depth from 5 to $7 \mathrm{~cm}$. The fresh snow at the surface contains less LAI compared to the dusty layer. Therefore, actinic flux values are higher in the top several centimeters of snow compared to actinic flux values measured before the snowfall event, even though $r_{\mathrm{e}}$ values in the new snow are a factor of 3.3-8.3 times smaller than the underlying depth hoar grains. Smaller $r_{\mathrm{e}}$ values lead to more scattering in the snow, which increases the probability of absorption by LAI. Although actinic flux values are highest at the surface on 31 January, Fig. 4b illustrates that UV radiation is rapidly attenuated below the fresh snow layer because radiation is forward-scattered into the highly absorbing dusty layer. As a result, there is roughly an order of magnitude less actinic flux at $14 \mathrm{~cm}$ depth on 31 January compared to 22 January.

The presence of a new dusty layer on the snow surface five days after the fresh snowfall event does not significantly alter the vertical profile of normalized UV actinic flux, likely 


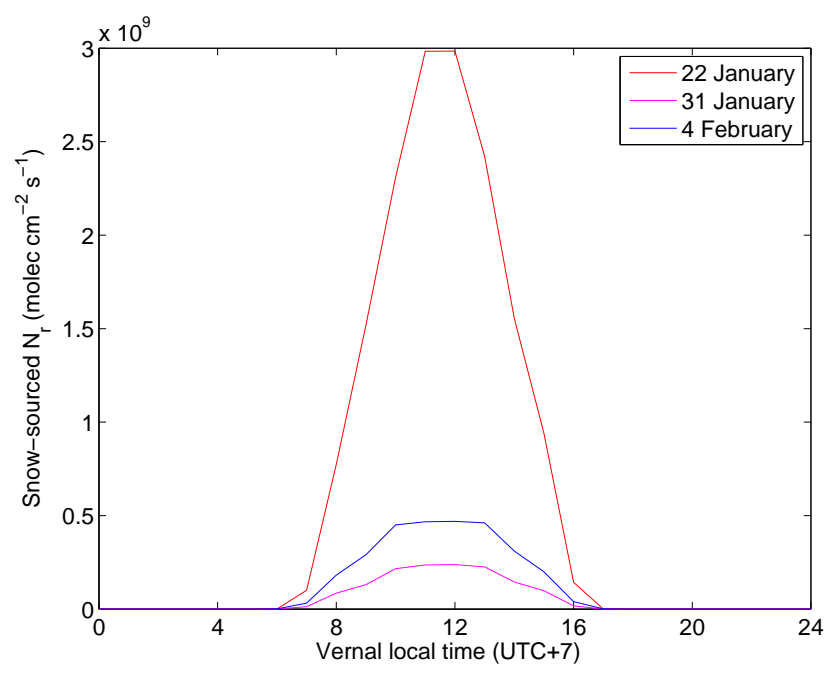

Figure 5. Modeled diurnal profiles of snow-sourced $\mathrm{N}_{\mathrm{r}}$ fluxes $\left(F_{\mathrm{N}_{\mathrm{r}}}\right.$, molec $\mathrm{cm}^{-2} \mathrm{~s}^{-1}$ ) calculated using TRANSITS on 22 January (red), 31 January (magenta), and 4 February (blue).

because UV absorption by LAI in the surface layer is at least five times lower than UV absorption by LAI in the original dusty layer (surface snow from 22 January snow pit). Surface snow UV albedo is strongly influenced by the presence of LAI, and Fig. S2b in the Supplement shows that snow UV albedo is lowest right before the snowfall event on 30-31 January and highest immediately afterwards.

We use these actinic flux profiles and the observed snow nitrate concentrations (Fig. 3a-c) to calculate daily averaged fluxes of snow-sourced $\mathrm{N}_{\mathrm{r}}\left(\right.$ molec $\left.\mathrm{cm}^{-2} \mathrm{~s}^{-1}\right)$ at $1 \mathrm{~cm}$ depth (z) increments in the snow $\left(F_{\mathrm{N}_{\mathrm{r}}}(z)\right)$, and total fluxes of $\mathrm{N}_{\mathrm{r}}$ to the boundary layer $\left(F_{\mathrm{N}_{\mathrm{r}}}\right)$ according to Eqs. (2) and (3) for each of the three snow pits (Fig. 4d-f). Prior to the fresh snowfall event, $F_{\mathrm{N}_{\mathrm{r}}}(z)$ decreases exponentially with depth in the photic zone. $F_{\mathrm{N}_{\mathrm{r}}}(z)$ is highest at the snow surface because that is where both actinic flux and snow nitrate concentrations are highest. Daily average $F_{\mathrm{N}_{\mathrm{r}}}$ summed over the snow photic zone is $5.6 \times 10^{8}$ molec $\mathrm{cm}^{-2} \mathrm{~s}^{-1}$ on $22 \mathrm{Jan}-$ uary (Fig. $4 \mathrm{~d}$ and Table 1). Immediately following the fresh snowfall event, $F_{\mathrm{N}_{\mathrm{r}}}(z)$ decreases by a factor of 3 at the surface because of the factor of 4 decrease in surface snow nitrate concentrations, which is partially compensated for by the higher UV actinic flux in the top of the snow photic zone (Fig. 4b). The daily averaged $F_{\mathrm{N}_{\mathrm{r}}}$ on 31 January is $1.9 \times 10^{8}$ molec $\mathrm{cm}^{-2} \mathrm{~s}^{-1}$, which is a factor of 3 lower than total $F_{\mathrm{N}_{\mathrm{r}}}$ on 22 January. Five days later, $F_{\mathrm{N}_{\mathrm{r}}}(z)$ has increased by a factor of 2 at the surface due to the factor of 2 increase in surface nitrate concentrations (Figs. $3 \mathrm{c}$ and $4 \mathrm{f}$ ). The daily averaged $F_{\mathrm{N}_{\mathrm{r}}}$ on 4 February is $3.2 \times 10^{8} \mathrm{molec} \mathrm{cm}^{-2} \mathrm{~s}^{-1}$, which is a factor of 1.7 higher than total $F_{\mathrm{N}_{\mathrm{r}}}$ on 31 January.

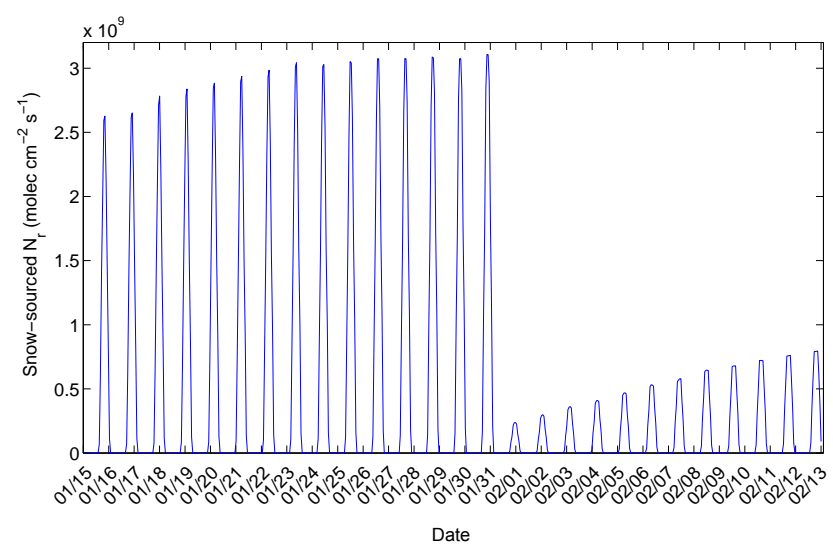

Figure 6. Modeled snow-sourced $\mathrm{N}_{\mathrm{r}}$ fluxes $\left(\right.$ molec $\mathrm{cm}^{-2} \mathrm{~s}^{-1}$ ) for each hour during the campaign from 15 January to 11 February.

\subsubsection{Snow photochemistry column model}

The snow chemistry column model is used to calculate the time-dependent flux of snow-sourced $\mathrm{N}_{\mathrm{r}}\left(F_{\mathrm{N}_{\mathrm{r}}}\right)$ and the depth profile of nitrate concentration and $\delta^{15} \mathrm{~N}\left(\mathrm{NO}_{3}^{-}\right)$. Figure 5 shows the diurnal $F_{\mathrm{N}_{\mathrm{r}}}$ values on 22, 31 January, and 4 February. The daily averaged snow $F_{\mathrm{N}_{\mathrm{r}}}$ on 22 January is $6.3 \times 10^{8}$ molec $\mathrm{cm}^{-2} \mathrm{~s}^{-1}$. Immediately following the snow event, the daily averaged snow $F_{\mathrm{N}_{\mathrm{r}}}$ decreases by a factor of 11 compared to 22 January $\left(5.6 \times 10^{7} \mathrm{molec} \mathrm{cm}^{-2} \mathrm{~s}^{-1}\right)$. The dramatic difference in $F_{\mathrm{N}_{\mathrm{r}}}$ is due to the differences in nitrate concentrations in the top several centimeters of snow. Modeled snow nitrate concentrations in the fresh snow layer on 31 January are between 30 and 300 times lower compared to nitrate concentrations in the dusty layer. Five days after the snow event, the daily averaged snow $F_{\mathrm{N}_{\mathrm{r}}}$ has increased by a factor of $2\left(1.2 \times 10^{8}\right.$ molec $\left.\mathrm{cm}^{-2} \mathrm{~s}^{-1}\right)$ because deposition of nitrate to the snow surface layer enhances surface nitrate concentrations and thus $F_{\mathrm{N}_{\mathrm{r}}}$. Calculated daily average $F_{\mathrm{N}_{\mathrm{r}}}$ using observed (Sect. 3.2.1) and modeled (TRANSITS) snow nitrate concentrations agree within a factor of $\sim 2(\mathrm{Ta}-$ ble 1); modeled $F_{\mathrm{N}_{\mathrm{r}}}$ tends to be lower because modeled snow nitrate concentrations are lower than observed (Fig. 3).

Figure 6 shows hourly $F_{\mathrm{N}_{\mathrm{r}}}$ values calculated for the entire UBWOS2014 campaign using TRANSITS. From the start of the campaign until the fresh snow event on 31 January, the daily maximum $F_{\mathrm{N}_{\mathrm{r}}}$ values increase as surface snow nitrate concentrations increase due to continual dry-deposition of atmospheric nitrate to the snow surface. Immediately after the snow event on 31 January, daily maximum $F_{\mathrm{N}_{\mathrm{r}}}$ values are lowered by more than a factor of 10 due to decreased nitrate concentrations in the snow photic zone. Following the snow event, the flux of snow-sourced $\mathrm{N}_{\mathrm{r}}$ gradually increases again due to dry-deposition of nitrate to the surface layer, although daily maximum $F_{\mathrm{N}_{\mathrm{r}}}$ values remain lower throughout the remainder of the field campaign compared to values before the snow event. 
Table 1. Snow photic zone depth and daily averaged modeled $F_{\mathrm{N}_{\mathrm{r}}}$ calculated using Eq. (3) and the TRANSITS model on 22,31 January, and 4 February.

\begin{tabular}{lcrrr}
\hline Pit date & $\begin{array}{c}\text { Photic zone } \\
\text { depth }(\mathrm{cm})\end{array}$ & \multicolumn{3}{c}{$\begin{array}{c}\text { Daily-averaged } F_{\mathrm{N}_{\mathrm{r}}} \\
\left(\text { molec cm }{ }^{-2} \mathrm{~s}^{-1}\right)\end{array}$} \\
\cline { 3 - 5 } & & Eq. (3) & $\begin{array}{r}\text { TRANSITS } \\
\left(\phi=4.6 \times 10^{-3}\right)\end{array}$ & $\begin{array}{r}\text { TRANSITS } \\
(\phi=0.2)\end{array}$ \\
\hline 22 January & 5.0 & $5.6 \times 10^{8}$ & $6.3 \times 10^{8}$ & $2.9 \times 10^{10}$ \\
31 January & 7.0 & $1.9 \times 10^{8}$ & $5.6 \times 10^{7}$ & $2.7 \times 10^{9}$ \\
4 February & 7.0 & $3.2 \times 10^{8}$ & $1.2 \times 10^{8}$ & $5.6 \times 10^{9}$ \\
\hline
\end{tabular}

Figure 3 shows modeled snow nitrate concentrations and $\delta^{15} \mathrm{~N}\left(\mathrm{NO}_{3}^{-}\right)$from TRANSITS compared to the observations. The general shapes of the modeled and measured vertical profiles of nitrate concentration are in agreement for all three snow pits; both modeled and measured nitrate concentrations are highest in the dusty layer and lowest near the bottom of the snow pit (Fig. 3a-c). Both the model and the observations show increased snow nitrate concentrations at the surface following the fresh snowfall event, but the model tends to underestimate surface snow nitrate concentrations after the snow event.

Modeled $\delta^{15} \mathrm{~N}\left(\mathrm{NO}_{3}^{-}\right)$is also within the range of observations (Fig. 3d-f). Modeled $\delta^{15} \mathrm{~N}\left(\mathrm{NO}_{3}^{-}\right)$at the top surface snow layer becomes more depleted from the 22 to 31 January snow pit, reflecting the decrease in atmospheric $\delta^{15} \mathrm{~N}\left(\mathrm{NO}_{3}^{-}\right)$in the model based on surface snow observations (Fig. 1a). Without additional snowfall between 31 January and 4 February, surface snow $\delta^{15} \mathrm{~N}\left(\mathrm{NO}_{3}^{-}\right)$becomes more enriched in the model during this time because model atmospheric $\delta^{15} \mathrm{~N}\left(\mathrm{NO}_{3}^{-}\right)$becomes more enriched (Fig. 1a). In contrast, the observations retain this low $\delta^{15} \mathrm{~N}\left(\mathrm{NO}_{3}^{-}\right)$at a depth of $\sim 2 \mathrm{~cm}$ until the 11 February snow pit (see Supplement A). The difference between modeled and observed $\delta^{15} \mathrm{~N}\left(\mathrm{NO}_{3}^{-}\right)$at $2 \mathrm{~cm}$ depth after 31 January may be due to the redistribution of surface snow by wind, and the fact that each snow pit was dug in a slightly different location. Blowing snow will bury the surface snow with low $\delta^{15} \mathrm{~N}\left(\mathrm{NO}_{3}^{-}\right)$, and subsequent atmospheric deposition of more enriched $\delta^{15} \mathrm{~N}\left(\mathrm{NO}_{3}^{-}\right)$will occur onto this new, wind-blown snow surface, retaining the light $\delta^{15} \mathrm{~N}\left(\mathrm{NO}_{3}^{-}\right)$at $2 \mathrm{~cm}$ depth. In contrast to the observations, the model does not account for windblown redistribution of snow and calculates the time evolution of nitrate concentration and $\delta^{15} \mathrm{~N}\left(\mathrm{NO}_{3}^{-}\right)$gradients of a single snow pit.

To examine the sensitivity of snow nitrate to photolysis, we turn off photolysis of snow nitrate in the model by setting $\phi=0$. When snow nitrate photolysis is turned off, snow nitrate concentrations change by less than $0.5 \%$ in all snow pits, resulting in relatively little sensitivity of modeled snow nitrate concentration to snow photochemistry because only this small fraction $(<0.5 \%)$ of nitrate is lost via photolysis at all depths. Despite the large nitrogen isotope fractionation ( $\varepsilon=-88$ to $-35 \%$ ) resulting from the photolysis of snow nitrate, the difference in modeled $\delta^{15} \mathrm{~N}\left(\mathrm{NO}_{3}^{-}\right)$when snow nitrate is turned on $\left(\phi=4.6 \times 10^{-3}\right)$ and off $(\phi=0)$ is small because of the very small fraction of nitrate photolyzed.

In another sensitivity study, we calculate the maximum possible $F_{\mathrm{N}_{\mathrm{r}}}$ in the Uintah Basin by increasing the value of $\phi$ until modeled snow $\delta^{15} \mathrm{~N}\left(\mathrm{NO}_{3}^{-}\right)$falls outside the full range of observations. Above $\phi=0.2$, there is significant disagreement (when the maximum change in $\delta^{15} \mathrm{~N}\left(\mathrm{NO}_{3}^{-}\right)$is $>1 \sigma$ of the mean $\delta^{15} \mathrm{~N}\left(\mathrm{NO}_{3}^{-}\right)$in all snow pits) between modeled and measured $\delta^{15} \mathrm{~N}\left(\mathrm{NO}_{3}^{-}\right)$values. Using $\phi=0.2$ results in more enriched $\delta^{15} \mathrm{~N}\left(\mathrm{NO}_{3}^{-}\right)$at depth due to enhanced photolytic loss, and more depleted $\delta^{15} \mathrm{~N}\left(\mathrm{NO}_{3}^{-}\right)$at the snow surface due to the deposition of isotopically light snow-sourced nitrate. Using $\phi=0.2$ results in a maximum possible $F_{\mathrm{N}_{\mathrm{r}}}$ at least 45 times larger than when using $\phi=4.6 \times 10^{-3}$ for all snow pits (see Table 1).

\section{Impact of snow-sourced $N_{r}$ on the boundary layer reactive nitrogen budget}

\section{1 $\mathrm{NO}_{x}$}

We first assume that all $\mathrm{N}_{\mathrm{r}}$ is $\mathrm{NO}_{x}$ and use $F_{\mathrm{N}_{\mathrm{r}}}$ values calculated using the snow photochemistry column model to estimate the impact of $F_{\mathrm{NO}_{x}}$ on the $\mathrm{NO}_{x}$ budget in the Uintah Basin. Using the best estimate for the quantum yield of nitrate photolysis $\left(\phi=4.6 \times 10^{-3}\right)$, the modeled daily averaged flux of snow-sourced $\mathrm{NO}_{x}$ ranges from $5.6 \times 10^{7}$ to $7.2 \times 10^{8}$ molec $\mathrm{cm}^{-2} \mathrm{~s}^{-1}$ and the maximum $F_{\mathrm{N}_{\mathrm{r}}}$ value is $3.1 \times 10^{9}$ molec $\mathrm{cm}^{-2} \mathrm{~s}^{-1}$ for the entire campaign (Supplement Table S4b). The top-down $\mathrm{NO}_{x}$ emission inventory for oil, gas, and all other sources, excluding the Bonanza power plant in Duchesne and Uintah counties, is $6.5 \times$ $10^{6} \mathrm{~kg} \mathrm{NO}_{x}$ year $^{-1}$ (Ahmadov et al., 2015). The power plant is excluded because its emissions occur above the boundary layer due to the plume's positive buoyancy. Assuming a constant $\mathrm{NO}_{x}$ emission rate and using the area of Duchesne $\left(8433 \mathrm{~km}^{2}\right)$ and Uintah counties $\left(11658 \mathrm{~km}^{2}\right)$, the top-down $\mathrm{NO}_{x}$ emission estimate for the Uintah and Duchesne coun- 
ties is $1.2 \times 10^{12}$ molec $\mathrm{cm}^{-2} \mathrm{~s}^{-1}$. The emission of primary $\mathrm{NO}_{x}$ in these two counties is thus at least 300 times higher than the estimated snow $\mathrm{NO}_{x}$ emissions, implying that snowsourced $\mathrm{NO}_{x}$ fluxes likely do not influence the $\mathrm{NO}_{x}$ boundary layer budget in the highly polluted Uintah Basin. If the upper limit of $\phi=0.2$ is used, snow-sourced $\mathrm{NO}_{x}$ emissions are still at least seven times smaller than primary $\mathrm{NO}_{x}$ emissions. Although reactive nitrogen is likely being emitted from the snow into the boundary layer, the snow-sourced $\mathrm{NO}_{x}$ signal is swamped by emissions from primary anthropogenic sources in the Uintah Basin.

\subsection{HONO}

Only the major channel for snow nitrate photolysis (Reaction R1) is simulated in the TRANSITS model, although nitrate can also photolyze via Reaction (R2) and form both $\mathrm{NO}_{x}$ and HONO (Reactions R3-R5). The surface snow pH ranged from 2 to 4 during the campaign (see Fig. S3a in the Supplement), which is low enough to enable direct volatilization of HONO from the snow. We estimate the maximum possible influence of the snow-photolytic source of boundary layer $\mathrm{HONO}$ by assuming that all snow-sourced $\mathrm{N}_{\mathrm{r}}$ is in the form of HONO. If we assume that the campaignmaximum $F_{\mathrm{N}_{\mathrm{r}}}$ value $\left(3.1 \times 10^{9}\right.$ molec $\left.\mathrm{cm}^{-2} \mathrm{~s}^{-1}\right)$ is all $\mathrm{HONO}$ that escapes from the snow into the boundary layer, with a layer height of $50 \mathrm{~m}$ and a lifetime of HONO of $18 \mathrm{~min}$ (at solar noon) (Edwards et al., 2013), snow nitrate photolysis would contribute a maximum of $25 \mathrm{pptv}$ of HONO to the boundary layer at solar noon. The modeled and observed Uintah Basin boundary layer HONO mixing ratios presented in Edwards et al. (2014) range from $\sim 20$ pptv at night to up to 150 pptv during the day, which suggests that the daytime fluxes of reactive nitrogen are not a significant source of HONO to the boundary layer compared to other HONO sources in the basin. Our estimated maximum HONO flux is comparable to snow-sourced HONO fluxes measured at another polluted, mid-latitude location (Paris, France), estimates of which ranged from 0.7 to $3.1 \times 10^{10}$ molec $\mathrm{cm}^{-2} \mathrm{~s}^{-1}$ (assuming a snow density of $0.36 \mathrm{~g} \mathrm{~cm}^{-3}$ and snow photic zone depth of $6 \mathrm{~cm}$ ) (Michoud et al., 2015). If the upper limit of $\phi=0.2$ is used (campaign-maximum $F_{\mathrm{N}_{\mathrm{r}}}=1.4 \times$ $10^{11}$ molec $\mathrm{cm}^{-2} \mathrm{~s}^{-1}$ ), the maximum boundary layer HONO mixing ratio calculated using this approach is $1.1 \mathrm{ppbv}$ at solar noon, which would significantly impact boundary layer HONO mixing ratios in the Uintah Basin. Given that HONO is thought to be only a minor fraction of total $\mathrm{N}_{\mathrm{r}}$ emitted from snow (Beine et al., 2008), we consider this to be an overestimate.

\section{Conclusions}

This study estimates the influence of snow nitrate photolysis on the boundary layer reactive nitrogen $\left(\mathrm{N}_{\mathrm{r}}\right)$ budget in the Uintah Basin, which is a region with heavy oil and natural gas extraction processes. Observations of snow optical properties, including ultraviolet (UV) light-absorbing impurities (e.g., black carbon, dust, and organics), radiation equivalent ice grain radii, and snow density from 12 snow pits measured during the Uintah Basin Winter Ozone Study (UBWOS) 2014 are incorporated into a snowpack radiative transfer model to calculate vertical profiles of UV actinic flux in 12 snow pits dug during the campaign. The calculated UV actinic flux profiles along with measurements of nitrate concentration are used to calculate snow-sourced $\mathrm{N}_{\mathrm{r}}$ fluxes associated with snow nitrate photolysis using both a simple Eq. (3) and a more complex snow photochemistry column model, which yield similar results. Snow nitrate photolysis in the column model is constrained by $1 \mathrm{~cm}$ depth-resolved observations of $\delta^{15} \mathrm{~N}\left(\mathrm{NO}_{3}^{-}\right)$in the snow pits, which is highly sensitive to UV photolysis (Erbland et al., 2015).

The daily averaged flux snow-sourced $\mathrm{N}_{\mathrm{r}}\left(F_{\mathrm{N}_{\mathrm{r}}}\right)$ to the boundary layer ranges from $5.6 \times 10^{7}$ to $7.2 \times$ $10^{8}$ molec $\mathrm{cm}^{-2} \mathrm{~s}^{-1}$ and the modeled campaign-maximum $F_{\mathrm{N}_{\mathrm{r}}}$ is $3.1 \times 10^{9}$ molec cm $^{-2} \mathrm{~s}^{-1}$. The top-down emission estimate of primary $\mathrm{NO}_{x}$ in Uintah and Duchesne counties reported in Ahmadov et al. (2015) is at least 300 times higher than estimated snow $\mathrm{NO}_{x}$ emissions, assuming that all $\mathrm{N}_{\mathrm{r}}$ is emitted as $\mathrm{NO}_{x}$. This suggests that snow-sourced $\mathrm{NO}_{x}$ fluxes likely have little influence on the boundary layer $\mathrm{NO}_{x}$ budget in the highly polluted Uintah Basin. Assuming that all $\mathrm{N}_{\mathrm{r}}$ is emitted as HONO also suggests that the snow-sourced reactive nitrogen fluxes associated with snow nitrate photolysis do not significantly contribute to boundary layer HONO mixing ratios in the Uintah Basin. The relative importance of the flux of $\mathrm{NO}_{x}$ and HONO will influence the impact of the recycling of $\mathrm{N}_{\mathrm{r}}$ in snow on the chemistry of the boundary layer in snow-covered regions but is unknown. Knowledge of the chemical speciation of snow-source $\mathrm{N}_{\mathrm{r}}$ is required for a better understanding of the full impact of snow on local oxidant budgets. However, in the Uintah Basin, we conclude that air quality models can safely neglect the recycling of reactive nitrogen in snow when identifying the most effective strategies for reducing wintertime ozone abundances.

\section{Data availability}

Our field and laboratory measurements are permanently archived in the University of Washington Libraries ResearchWorks Archive: https://digital.lib.washington.edu/ researchworks/handle/1773/37311.

The Supplement related to this article is available online at doi:10.5194/acp-16-13837-2016-supplement. 
Acknowledgements. We gratefully acknowledge support from 155 backers from http://www.experiment.com, NSF PLR 1244817, PMEL contribution number 4468, and an EPA STAR fellowship to M. C. Zatko. The Uintah Basin Winter Ozone Studies were a collaborative project led and coordinated by the Utah Department of Environmental Quality (UDEQ) with support from the Uintah Impact Mitigation Special Service District (UIMSSD), the Bureau of Land Management (BLM), the Environmental Protection Agency (EPA), and Utah State University. The authors acknowledge the NOAA/ESRL Chemical Sciences Division and Questar Energy Products for site preparation and support. We thank Kristen Shultz, Jim Johnson, Drew Hamilton, and Derek Coffman for all of their help before, during, and after the field campaign. We would also like to thank Dean Hegg for advice on aerosol sampling, Angela Hong and Jennifer Murphy for helpful discussions about $\mathrm{NO}_{y}$ vertical gradients, and Chad Mangum for laboratory assistance at USU. We thank Sarah Doherty for the use of the ISSW spectrophotometer and Stephen Warren for graciously allowing M. C. Zatko to borrow snow sampling instruments and gear and providing comments about this work. We thank Jonathan Raff for helpful discussions about soil microbial activity as well as Joost de Gouw and Gail Tonnesen for useful discussions about boundary layer HONO. Finally, we thank Lyatt Jaeglé, Joel Thornton, and Thomas Grenfell for their helpful comments. Joel Savarino and Joseph Erbland have been partly supported by a grant from Labex OSUG@2020 (Investissements d'avenir - ANR10 LABX56) during the development of the TRANSITS model.

Edited by: P. B. Shepson

Reviewed by: two anonymous referees

\section{References}

Ahmadov, R., McKeen, S., Trainer, M., Banta, R., Brewer, A., Brown, S., Edwards, P. M., de Gouw, J. A., Frost, G. J., Gilman, J., Helmig, D., Johnson, B., Karion, A., Koss, A., Langford, A., Lerner, B., Olson, J., Oltmans, S., Peischl, J., Pétron, G., Pichugina, Y., Roberts, J. M., Ryerson, T., Schnell, R., Senff, C., Sweeney, C., Thompson, C., Veres, P. R., Warneke, C., Wild, R., Williams, E. J., Yuan, B., and Zamora, R.: Understanding high wintertime ozone pollution events in an oil- and natural gasproducing region of the western US, Atmos. Chem. Phys., 15, 411-429, doi:10.5194/acp-15-411-2015, 2015.

Anastasio, C. and Chu, L.: Photochemistry of nitrous acid (HONO) and nitrous acidium ion $\left(\mathrm{H}_{2} \mathrm{ONO}^{+}\right)$in aqueous solution and ice, Environ. Sci. Technol., 43, 1108-1114, 2009.

Beine, H., Colussi, A. J., Amoroso, A., Esposito, G., Montagnoli, M., and Hoffman, M. R.: HONO emissions from snow, Environ. Res. Lett., 3, 045005, doi:10.1088/1748-9326/3/4/045005, 2008.

Berhanu, T. A., Meusinger, C., Erbland, J., Jost, R., Bhattcharya, S. K., Johnson, M. S., and Savarino, J.: Laboratory study of nitrate photolysis in Antarctic snow. II. Isotopic effects and wavelength dependence, J. Chem. Phys., 140, 244306, doi:10.1063/1.4882899, 2014.

Carter, W. P. L. and Seinfeld, J. H.: Winter $\mathrm{O}_{3}$ formation and VOC incremental reactivities in the Upper Green
River Basin of Wyoming, Atmos. Environ., 50, 255-266, doi:10.1016/j.atmosenv.2011.12.025, 2012.

Casciotti, K. L., Sigman, D. M., Hastings, M., Bohlke, J. K., and Hilkert, A.: Measurement of the oxygen isotopic composition of nitrate in seawater and freshwater using the denitrifier method, Anal. Chem., 74, 4905-4912, 2002.

Chu, L. and Anastasio, C.: Quantum Yields of Hydroxyl Radicals and Nitrogen Dioxide from the Photolysis of Nitrate on Ice, J. Phys. Chem., 107, 9594-9602, 2003.

Crowley, J. N., Ammann, M., Cox, R. A., Hynes, R. G., Jenkin, M. E., Mellouki, A., Rossi, M. J., Troe, J., and Wallington, T. J.: Evaluated kinetic and photochemical data for atmospheric chemistry: Volume V - heterogeneous reactions on solid substrates, Atmos. Chem. Phys., 10, 9059-9223, doi:10.5194/acp-10-90592010, 2010.

Delmas, R., Serca, D., and Jambert, C.: Global inventory of $\mathrm{NO}_{x}$ sources, Nutr. Cycl. Agroecosys., 48, 51-60, 1997.

Doherty, S. J., Warren, S. G., Grenfell, T. C., Clarke, A. D., and Brandt, R. E.: Light-absorbing impurities in Arctic snow, Atmos. Chem. Phys., 10, 11647-11680, doi:10.5194/acp-1011647-2010, 2010.

Domine, F., Bock, J., Voisin, D., and Donaldson, D. J.: Can we model snow photochemistry? Problems with the current approaches, J. Phys. Chem. A, 117, 4733-4749, doi:10.1021/jp3123314, 2013.

Durham, J. L. and Stockburger, L.: Nitric acid-air diffusion coefficient: Experimental determination, Atmos. Environ., 20, 559563, 1986.

Edwards, P. M., Young, C. J., Aikin, K., deGouw, J., Dubé, W. P., Geiger, F., Gilman, J., Helmig, D., Holloway, J. S., Kercher, J., Lerner, B., Martin, R., McLaren, R., Parrish, D. D., Peischl, J., Roberts, J. M., Ryerson, T. B., Thornton, J., Warneke, C., Williams, E. J., and Brown, S. S.: Ozone photochemistry in an oil and natural gas extraction region during winter: simulations of a snow-free season in the Uintah Basin, Utah, Atmos. Chem. Phys., 13, 8955-8971, doi:10.5194/acp-13-8955-2013, 2013.

Edwards, P. M., Brown, S., Roberts, J., Ahmadov, R., Banta, R., de Gouw, J., Dube, W., Field, R., Flynn, J., Gilman, J., Graus, M., Helmig, D., Koss, A., Langford, A., Lefer, B., Lerner, B., Li, R., Li, S., McKeen, S., Murphy, S., Parrish, D., Senff, C., Soltis, J., Stutz, J., Sweeney, C., Thompson, C., Trainer, M., Tsai, C., Veres, P., Washenfelder, R., Warneke, C., Wild, R., Young, C., Yuan, B., and Zamora, R.: High $\mathrm{O}_{3}$ pollution from carbonyl photolysis in an oil and gas basin, Nature, 514, 351354, doi:10.1038/nature13767, 2014.

Erbland, J., Vicars, W. C., Savarino, J., Morin, S., Frey, M. M., Frosini, D., Vince, E., and Martins, J. M. F.: Air-snow transfer of nitrate on the East Antarctic Plateau - Part 1: Isotopic evidence for a photolytically driven dynamic equilibrium in summer, Atmos. Chem. Phys., 13, 6403-6419, doi:10.5194/acp-136403-2013, 2013.

Erbland, J., Savarino, J., Morin, S., France, J. L., Frey, M. M., and King, M. D.: Air-snow transfer of nitrate on the East Antarctic Plateau - Part 2: An isotopic model for the interpretation of deep ice-core records, Atmos. Chem. Phys., 15, 12079-12113, doi:10.5194/acp-15-12079-2015, 2015.

Felix, J. D. and Elliot, E. M.: Isotopic composition of passively collected nitrogen dioxide emissions: Vehicle, soil and 
livestock source signatures, Atmos. Environ., 92, 359-366, doi:10.1016/j.atmosenv.2014.04.005, 2014.

Felix, J. D., Elliott, E. M., and Shaw, S.L: Nitrogen isotopic composition of coal-fired power plant $\mathrm{NO}_{x}$ : Influence of emissions controls and implications for global emission inventories, Environ. Sci. Technol., 46, 3528-3535, 2012.

Field, R. A., Soltis, J., McCarthy, M. C., Murphy, S., and Montague, D. C.: Influence of oil and gas field operations on spatial and temporal distributions of atmospheric non-methane hydrocarbons and their effect on ozone formation in winter, Atmos. Chem. Phys., 15, 3527-3542, doi:10.5194/acp-15-3527-2015, 2015.

Frey, M. M., Savarino, J., Morin, S., Erbland, J., and Martins, J. M. F.: Photolysis imprint in the nitrate stable isotope signal in snow and atmosphere of East Antarctica and implications for reactive nitrogen cycling, Atmos. Chem. Phys., 9, 8681-8696, doi:10.5194/acp-9-8681-2009, 2009.

Freyer, H. D., Kley, D., Volz-Thomas, A., and Kobel, K.: On the interaction of isotopic exchange processes with photochemical reactions in atmospheric oxides of nitrogen, J. Geophys. Res., 98, 14791-14786, doi:10.1029/93JD00874, 1993.

Gilman, J. B., Lerner, B. M., Kuster, W. C., de Gouw, J. A.: Source signature of volatile organic compounds from oil and natural gas operations in northeastern Colorado, Environ. Sci. Technol., 47, 1297-1305, doi:10.1021/es304119a, 2013.

Grannas, A. M., Jones, A. E., Dibb, J., Ammann, M., Anastasio, C., Beine, H. J., Bergin, M., Bottenheim, J., Boxe, C. S., Carver, G., Chen, G., Crawford, J. H., Dominé, F., Frey, M. M., Guzmán, M. I., Heard, D. E., Helmig, D., Hoffmann, M. R., Honrath, R. E., Huey, L. G., Hutterli, M., Jacobi, H. W., Klán, P., Lefer, B., McConnell, J., Plane, J., Sander, R., Savarino, J., Shepson, P. B., Simpson, W. R., Sodeau, J. R., von Glasow, R., Weller, R., Wolff, E. W., and Zhu, T.: An overview of snow photochemistry: evidence, mechanisms and impacts, Atmos. Chem. Phys., 7, 43294373, doi:10.5194/acp-7-4329-2007, 2007.

Grenfell, T. C.: A Radiative Transfer Model for Sea Ice With Vertical Structure Variations, J. Geophys. Res., 96, 16991-17001, 1991.

Grenfell, T. C. and Warren, S. G.: Representation of a nonspherical ice particle by a collection of independent spheres for scattering and absorption of radiation, J. Geophys. Res., 104, 3169731709, 1999.

Grenfell, T. C., Doherty, S. J., Clarke, A. D., and Warren, S. G.: Light absorption from particulate impurities in snow and ice determined by spectrophotometric analysis of filters, Appl. Optics, 50, 2037-2048, doi:10.1364/AO.50.002037, 2011.

Guenther, A., Hewitt, N. C., Erickson, D., Fall, R., Geron, C., Graedel, T., Harley, P., Klinger, L., Lerdau, M., McKay, W. A., Pierce, T., Scholes, B., Steinbrecher, R., Tallamraju, R., Taylor, J., and Zimmerman, P.: A global model of natural volatile organic compound emissions, J. Geophys. Res., 100, 8873-8892, 1995.

Hansen, J. E. and Travis, L. D.: Light scattering in planetary atmospheres, Space. Sci. Rev., 16, 527-610, 1974.

Heaton, T. H. E., Spiro, B., and Robertson, M. C.: Potential canopy influences on the isotopic composition of nitrogen and sulphur in atmospheric deposition, Oecologia, 109, 600-607, 1997.

Helmig, D., Thompson, C. R., Evans, J., Boylan, P., Hueber, J., and Park, J. H.: Highly elevated atmospheric levels of volatile organic compounds in the Uintah Basin, Utah, Environ. Sci. Technol., 48, 4707-4715, doi:10.1021/es405046r, 2014.
Honrath, R. E., Guo, S., Peterson, M. C., Dziobak, M. P., Dibb, J. E., and Arsenault, M. A.: Photochemical production of gas phase $\mathrm{NO}_{x}$ from ice crystal $\mathrm{NO}_{3}^{-}$, J. Geophys. Res., 105, $24183-$ 24190, 2000.

Kaiser, J., Hastings, M. G., Houlton, B. Z., Rockmann, T., and Sigman, D. M.: Triple oxygen isotope analysis of nitrate using the denitrifier method and thermal decomposition of $\mathrm{N}_{2} \mathrm{O}$, Anal. Chem., 79, 599-607, doi:10.1021/ac061022s, 2007.

Logan, J. A.: Nitrogen oxides in the troposphere: Global and regional budgets, J. Geophys. Res., 88, 10785-10807, doi:10.1029/JC088iC15p10785, 1983.

Mack, J. and Bolton, J. R.: Photochemistry of nitrite and nitrate in aqueous solution: A review, J. Photochem. Photobiol. A., 128, $1-13,1999$.

Markvart, T. and Castalzer, L.: Practical handbook of photovoltaics: fundamentals and applications, Elsevier, ISBN 1-85617-390-9, 2003.

Martin, R., Moore, K., Mansfield, M., Hill, S., Harper, K., and Shorthill, H.: Final report: Uintah Basin winter $\mathrm{O}_{3}$ and air quality study, December 2010-March 2011, Energy Dynamics Laboratory, document number: EDL/11-039, 2011.

Massman, W. J.: A review of the molecular diffusivities of $\mathrm{H}_{2} \mathrm{O}$, $\mathrm{CO}_{2}, \mathrm{CH}_{3}, \mathrm{CO}, \mathrm{O}_{3}, \mathrm{SO}_{2}, \mathrm{NH}_{3}, \mathrm{~N}_{2} \mathrm{O}, \mathrm{NO}$, and $\mathrm{NO}_{2}$ in air, $\mathrm{O}_{2}$ and $\mathrm{N}_{2}$ near STP, Atmos. Environ., 32, 1111-1127, doi:10.1016/S1352-2310(97)00391-9, 1998.

Matthias, A. D., Fimbres, A., Sano, E. E., Post, D. F., Accioly, L., Batchily, A. K., and Ferreira, L. G.: Surface roughness effects on soil albedo, Soil Sci. Soc. Am. J., 64, 1035-1041, 2000.

Meusinger, C., Berhanu, T. A., Erbland, J., Savarino, J., and Johnson, M. S.: Laboratory study of nitrate photolysis in Antarctic snow. I. Observed quantum yield, domain of photolysis, and secondary chemistry, J. Chem. Phys., 140, 244305, doi:10.1063/1.4882898, 2014.

Michoud, V., Doussin, Jean-Francois, Colomb, A., Afif, C., Borbon, A., Camredon, M., Aumont, B., Legrand, M., and Beekman, M.: Strong HONO formation in a suburban site during snowy days, Atmos. Environ., 116, 155-158, doi:10.1016/j.atmosenv.2015.06.040, 2015.

Morin, S., Savarino, J., Frey, M. M., Domine, F., Jacobi, H.-W., Kaleschke, L., and Martins, J. M. F.: Comprehensive isotopic composition of atmospheric nitrate in the Atlantic Ocean boundary layer from $65^{\circ} \mathrm{S}$ to $79^{\circ} \mathrm{N}$, J. Geophys. Res., 114, D05303, doi:10.1029/2008JD010696, 2009.

Oltmans, S. J., Schnell, R. C., Johnson, B. J., Petron, G., Mefford, T., and Neely III, R.: Anatomy of wintertime $\mathrm{O}_{3}$ production associated with oil and gas extraction activity in Wyoming and Utah, Elem. Sci. Anth., 2, 000024, doi:10.12952/journal.elementa.000024, 2014.

Quinn, P. K., Coffman, D. J., Kapustin, V. N., Bates, T. S., and Covert, D. S.: Aerosol optical properties in the MBL during ACE-1 and the underlying chemical and physical aerosol properties, J. Geophys. Res., 103, 16547-16564, 1998.

Quinn, P. K., Bates, T. S., Miller, T. L., Coffman, D. J., Johnson, J. E., Harris, J. M., Ogren, A., Forbes, G., Anderson, T. L., Covert, D. S., and Rood, M. J.: Surface submicron aerosol chemical composition: what fraction is not sulfate?, J. Geophys. Res., 105, 6785-6805, doi:10.1029/1999JD901034, 2000.

Rappenglück, B., Ackermann, L., Alvarez, S., Golovko, J., Buhr, M., Field, R. A., Soltis, J., Montague, D. C., Hauze, B., Adam- 
son, S., Risch, D., Wilkerson, G., Bush, D., Stoeckenius, T., and Keslar, C.: Strong wintertime ozone events in the Upper Green River basin, Wyoming, Atmos. Chem. Phys., 14, 4909-4934, doi:10.5194/acp-14-4909-2014, 2014.

Rolph, G. D.: Real-time Environmental Applications and Display sYstem (READY) Website, available at: http://www.ready.noaa. gov (last access: 31 July 2016), NOAA Air Resources Laboratory, College Park, MD, 2016.

Schnell, R. C., Oltmans, S. J., Neely, R. R., Endres, M. S., Molenar, J. V., and White, A. B.: Rapid photochemical production of $\mathrm{O}_{3}$ at high concentrations in a rural site during winter, Nat. Geosci., 2, 120-122, doi:10.1038/ngeo415, 2009.

Sigman, D. M., Casciotti, K. L., Andreani, M., Barford, C., Galanter, M., and Bohlke, J. K.: A bacterial method for the nitrogen isotopic analysis of nitrate in seawater and freshwater, Anal. Chem., 73, 4145-4153, doi:10.1021/ac010088e, 2001.

Silva, S. R., Kendall, C., Wilkinson, D. H., Ziegler, A. C., Chang, C. C. Y., and Avanzino, R. J.: A new method for collection of nitrate from fresh water and analysis of the nitrogen and oxygen isotope ratios, J. Hydrol., 228, 22-36, 2000.

Stamnes, K., Tsay, S., Wiscombe, W., and Jayaweera, K.: Numerically stable algorithm for discrete-ordinate-method radiative transfer in multiple scattering and emitting layered media, Appl. Optics, 27, 2502-2509, 1988.

Stein, A. F., Draxler, R. R, Rolph, G. D., Stunder, B. J. B., Cohen, M. D., and Ngan, F.: NOAA's HYSPLIT atmospheric transport and dispersion modeling system, B. Am. Meteorol. Soc., 96, 2059-2077, doi:10.1175/BAMS-D-14-00110.1, 2015.

Thompson, A. M.: The oxidizing capacity of the Earth's atmosphere: Probable past and future changes, Science, 256, 1157$1165,1992$.

US EIA (US Energy Information Administration): Annual energy outlook 2014 Early Release Overview, Office of Integrated and International Energy Analysis US Department of Energy, Washington, DC 20585, available at: http://www.eia.gov/forecasts/ aeo/er/pdf/0383er(2014).pdf (last access: 24 March 2015), 2014.

Veres, P. R., Roberts, J. M., Wild, R. J., Edwards, P. M., Brown, S. S., Bates, T. S., Quinn, P. K., Johnson, J. E., Zamora, R. J., and de Gouw, J.: Peroxynitric acid $\left(\mathrm{HO}_{2} \mathrm{NO}_{2}\right)$ measurements during the UBWOS 2013 and 2014 studies using iodide ion chemical ionization mass spectrometry, Atmos. Chem. Phys., 15, 81018114, doi:10.5194/acp-15-8101-2015, 2015.

Walters, W. W. and Michalski, G.: Theoretical calculation of nitrogen isotope equilibrium exchange fractionation factors for various $\mathrm{NO}_{y}$ molecules, Geochem. Cosmochem. Ac., 164, 284-297, doi:10.1016/j.gca.2015.05.029, 2015.

Warneke, C., Geiger, F., Edwards, P. M., Dube, W., Pétron, G., Kofler, J., Zahn, A., Brown, S. S., Graus, M., Gilman, J. B., Lerner, B. M., Peischl, J., Ryerson, T. B., de Gouw, J. A., and Roberts, J. M.: Volatile organic compound emissions from the oil and natural gas industry in the Uintah Basin, Utah: oil and gas well pad emissions compared to ambient air composition, Atmos. Chem. Phys., 14, 10977-10988, doi:10.5194/acp14-10977-2014, 2014

Warren, S. G., Brandt, R. E., and Grenfell, T. C.: Visible and nearultraviolet absorption spectrum of ice from transmission of solar radiation into snow, Appl. Optics., 45, 5320-5334, 2006.
Walters, W. W., Goodwin, S. R., and Michalski, G.: Nitrogen stable isotope composition $\delta^{15} \mathrm{~N}$ of vehicle-emitted $\mathrm{NO}_{x}$, Environ. Sci. Tech., 49, 2278-2285, doi:10.1021/es505580v, 2015.

Walters, W. W., Simonini, D. S., and Michalski, G.: Nitrogen isotope exchange between $\mathrm{NO}$ and $\mathrm{NO}_{2}$ and its implications for $\delta^{15} \mathrm{~N}$ variations in tropospheric $\mathrm{NO}_{x}$ and atmospheric nitrate, Geophys. Res. Lett., 43, 440-448, doi:10.1002/2015G1066438, 2016.

Wild, R. J., Edwards, P. M., Bates, T. S., Cohen, R. C., de Gouw, J. A., Dubé, W. P., Gilman, J. B., Holloway, J., Kercher, J., Koss, A. R., Lee, L., Lerner, B. M., McLaren, R., Quinn, P. K., Roberts, J. M., Stutz, J., Thornton, J. A., Veres, P. R., Warneke, C., Williams, E., Young, C. J., Yuan, B., Zarzana, K. J., and Brown, S. S.: Reactive nitrogen partitioning and its relationship to winter ozone events in Utah, Atmos. Chem. Phys., 16, 573583, doi:10.5194/acp-16-573-2016, 2016.

Wiscombe, W. J.: The delta-M method: Rapid yet accurate radiative flux calculations for strongly asymmetric phase functions, J. Atmos. Sci., 34, 1408-1422, 1977.

Yuan, B., Liggio, J., Wentzell, J., Li, S.-M., Stark, H., Roberts, J. M., Gilman, J., Lerner, B., Warneke, C., Li, R., Leithead, A., Osthoff, H. D., Wild, R., Brown, S. S., and de Gouw, J. A.: Secondary formation of nitrated phenols: insights from observations during the Uintah Basin Winter Ozone Study (UBWOS) 2014, Atmos. Chem. Phys., 16, 2139-2153, doi:10.5194/acp-16-21392016, 2016.

Zatko, M., Geng, L., Alexander, B., Sofen, E., and Klein, K.: The impact of snow nitrate photolysis on boundary layer chemistry and the recycling and redistribution of reactive nitrogen across Antarctica and Greenland in a global chemical transport model, Atmos. Chem. Phys., 16, 2819-2842, doi:10.5194/acp-16-28192016, 2016.

Zatko, M. C. and Warren, S. G.: East Antarctic sea ice in spring: spectral albedo of snow, nilas, frost flowers, and slush; and light-absorbing impurities in snow, Ann. Glaciol., 56, 53-64, doi:10.3189/2015AoG69A574, 2015.

Zatko, M. C., Grenfell, T. C., Alexander, B., Doherty, S. J., Thomas, J. L., and Yang, X.: The influence of snow grain size and impurities on the vertical profiles of actinic flux and associated $\mathrm{NO}_{x}$ emissions on the Antarctic and Greenland ice sheets, Atmos. Chem. Phys., 13, 3547-3567, doi:10.5194/acp-13-35472013, 2013.

Zhou, X., Beine, H. J., Honrath, R. E., Fuentes, J. D., Simpson, W., Shepson, P. B., and Bottenheim, J. W.: Snowpack photochemical production of HONO: a major source of $\mathrm{OH}$ in the Arctic boundary layer in springtime, Geophys. Res. Lett., 28, 4087 4090, 2001.

Zhu, C., Xiang, B., Chu, L. T., and Zhu, L.: 308 nm Photolysis of Nitric Acid in the Gas Phase, on Aluminum Surfaces, and on Ice Films, J. Phys. Chem. A, 114, 2561-2568, doi:10.1021/jp909867a, 2010. 